\title{
ENTRE A SOBERANIA E A GOVERNAMENTALIDADE NEOLIBERAL: O Processo de Privatização do Grupo Petrobras
}

\author{
Cláudio Luiz Zanotelli \\ Francismar Cunha Ferreiraii
}

\begin{abstract}
Resumo: o artigo procura, a partir da abordagem das categorias de análise, de prática e de norma do neoliberalismo e de soberania, trazer à luz os processos de privatização do grupo Petrobras desde 2016. O enquadramento institucional e a hegemonia do neoliberalismo no Estado brasileiro legitimam o desengajamento do governo da Petrobras. Realizamos um levantamento de todos os setores do grupo que foram privatizados, bem como constatamos a transferência gradual de parcelas do recurso de exploração e produção de petróleo para grandes grupos transnacionais. Nossa hipótese é a de que o regime neoliberal operou uma transformação da categoria de soberania colocando-a ao serviço da instituição do neoliberalismo e do desengajamento do Estado brasileiro das atividades econômicas. Nesse sentido, reivindicar a soberania por meio da reativação de conceitos do período nacional-desenvolvimentista brasileiro parece não ter surtido os efeitos esperados em termos de mobilização social contra a privatização da Petrobras.
\end{abstract}

Palavras-chave: Grupo Petrobras; neoliberalismo; soberania; privatização.

\section{BETWEEN SOVEREIGNTY AND NEOLIBERAL GOVERNMENTALITY: THE PETROBRAS GROUP'S PRIVATIZATION PROCESS}

\begin{abstract}
: based on the approach of the categories of analysis, practice and norms of neoliberalism and sovereignty, the paper seeks to bring to light the privatization processes of the Petrobras group from 2016 onwards. The institutional framework and the hegemony of neoliberalism in the Brazilian state legitimize the government disengagement from Petrobras. We carried out a survey of all the sectors of the group that were privatized, as well as the gradual transfer of portions of the oil exploration and production resource to large transnational groups. Our hypothesis is that the neoliberal regime transformed the category of sovereignty, placing it at the service of the institution of neoliberalism and the disengagement of the Brazilian State from economic activities. In this sense, claiming sovereignty through the reactivation of concepts such as sovereignty
\end{abstract}

\footnotetext{
i Professor Titular da Universidade Federal do Espírito Santo (UFES) e Bolsista de Produtividade do CNPQ nível PQ 2. Contato: claudio.zanotelli@ufes.br.

ii Doutorando em Geografia pela Universidade Federal do Espírito Santo (UFES). Contato: francismar.cunha@gmail.com.
} 
in the Brazilian national-developmental period does not seem to have had the expected effects in terms of social mobilization against the privatization of Petrobras.

Keywords: Petrobras Group; neoliberalism; sovereignty; privatization

\title{
ENTRE LA SOBERANÍA Y LA GUBERNAMENTALIDAD NEOLIBERAL: EL PROCESO DE PRIVATIZACIÓN DEL GRUPO PETROBRAS
}

\begin{abstract}
Resumen: a partir del abordaje de las categorías de análisis, práctica y normas del neoliberalismo y la soberanía, el artículo busca sacar a la luz los procesos de privatización del grupo Petrobras a partir de 2016. El marco institucional y la hegemonía del neoliberalismo en el Estado brasileño legitiman la desvinculación del gobierno de Petrobras. Realizamos un relevamiento de todos los sectores del grupo que fueron privatizados, así como verificamos la transferencia gradual de porciones del recurso de exploración y producción petrolera a grandes grupos transnacionales. Nuestra hipótesis es que el régimen neoliberal transformó la categoría de soberanía, poniéndola al servicio de la institución del neoliberalismo y la desvinculación del Estado brasileño de las actividades económicas. En este sentido, reclamar la soberanía a través de la reactivación de conceptos del período de desarrollo nacional brasileño no parece haber tenido los efectos esperados en términos de movilización social contra la privatización de Petrobras.

Palabras-clave: Grupo Petrobras; neoliberalismo; soberanía; privatización
\end{abstract}

\section{Introdução}

Desde quando se tornou a principal fonte da matriz energética da sociedade industrial, o petróleo e as atividades a ele ligadas se tornaram pontos de tensão geopolíticos. Diferentes agentes e lugares passaram a se articular muitas vezes de forma contraditória e conflituosa em torno do recurso em contextos econômicos e políticos diversos. 0 Brasil se insere nesse contexto de diferentes formas ao longo do tempo. Primeiramente, como simples importador de petróleo até meados do século XX. Em um segundo momento, o país desenvolve uma política nacionalista com a criação da Petrobras e o monopólio da União sobre as atividades petrolíferas. Finalmente, o terceiro momento ocorre após 1998, com a abertura das atividades petrolíferas ao mercado privado por meio da quebra do monopólio da União e da Petrobras sobre o setor e o seu ingresso na bolsa de valores de New York. 
A última etapa se desdobra a partir dos anos 2000 , em dois distintos processos que marcarão a história da companhia: primeiramente, o evento da descoberta dos grandes campos do "cluster" do pré-sal a partir de 2005, o que irá alterar a regulação estatal sobre o setor entre 2010 e 2013, procurando garantir um relativo controle do Estado e da empresa sobre esta "nova fronteira" de exploração em águas profundas; ${ }^{1}$ em segundo lugar, as transformações recentes que surgiram como desdobramento das grandes descobertas da empresa e a sua desestabilização por razões diversas, mas em particular por causa dos interesses dos grupos transnacionais pelo recurso e pelas empresas da cadeia do petróleo. Esse último processo se prolonga até os dias atuais, valendo-se de uma fragilidade institucional e econômica momentânea da empresa por causa da operação jurídico-política, com instrumentalização do exército brasileiro, e midiática da Lava Jato² a partir de 2014 e que culmina com as mudanças da regulação e da direção da empresa a partir de 2016. Isso acentuou o fatiamento do grupo Petrobras para venda no período atual e a aplicação do adágio neoliberal de modificar o papel do Estado, que deve enquadrar juridicamente o espaço econômico, mas não ser ator desse processo - o Estado como garantidor da Lei e da Ordem, responsável da "regulação", pois se supõe que a sua presença nas atividades econômicas provoque a centralização e eliminaria a concorrência pura e perfeita que se espera dos processos econômicos formais (FOUCAULT, 2004b).

A nossa análise busca aprofundar-se no que chamamos de terceira etapa, sobretudo dos períodos de mudanças mais recentes da regulação a partir de 2010 da indústria petrolífera brasileira. De forma mais detalhada propõe analisar os recentes processos

\footnotetext{
${ }^{1} \mathrm{O}$ livro de Marco Antônio P. Machado, Pré-sal: A saga. A história de uma das maiores descobertas mundiais de petróleo (MACHADO, 2018), retrata os bastidores de uma das grandes descobertas no mundo de petróleo no século XXI em águas ultra profundas, localizadas na Bacia sedimentar de Santos e podendo se estender até os limites territoriais de $\mathbf{2 0 0}$ milhas da Zona Econômica Exclusiva. O livro traduz os interesses em jogo na exploração do pré-sal, pois o autor fez parte da equipe de geólogos que participou da sua descoberta, além de efetuar uma cronologia da aventura do petróleo no Brasil com detalhes sobre o período do pré-sal. Uma das qualidades do livro é aquela de fornecer os detalhes técnicos e geológicos do fenômeno, bem como sua excepcionalidade, demonstrando, ademais, que do interior da própria Petrobras saíram pessoas que se mudaram de armas e bagagens para os concorrentes da empresa com dados sobre as descobertas, demonstrando uma total porosidade aos interesses individuais.

${ }^{2} \mathrm{~A}$ Lava Jato merece um capítulo à parte que não temos espaço aqui para desenvolver, mas sobre a qual realizamos uma primeira abordagem em ZANOTELLI et al (2020) e que pretendemos desenvolver posteriormente dentro do quadro de uma análise geopolítica.
} 
de privatização do grupo Petrobras. Deste modo, o artigo, que tem por base uma discussão sobre a instauração da governamentalidade neoliberal (LAVAL, 2018, FOUCAULT, 2004a e 2004b), tem como objetivo compreender os conceitos de soberania e de neoliberalismo aplicado ao Estado brasileiro, analisando o setor petrolífero a partir de alterações da regulação estatal e do recente e intenso processo de privatização e de da petroleira Petrobras.

Para realizar tal intento, metodologicamente, procedemos por meio do levantamento de dados relativos às privatizações do Grupo Petrobras junto à Agencia Nacional do Petróleo (ANP) acerca dos campos de produção, dos blocos de exploração e das bacias sedimentares, bem como a partir de dados do site da Petrobras, suas comunicações aos mercados, seu balanço e de seus teasers ${ }^{3}$ com os anúncios relativos a outros setores vendidos ou à venda do grupo. Finalmente, consultamos diversos jornais sobre as transações da Petrobras, buscando identificar o comprador dos ativos e os valores das negociações. Estabelecemos, assim, um quadro da situação socioeconômica e socioterritorial do grupo Petrobras.

Buscamos, ademais, operar uma leitura transversal destes processos a partir da compreensão do que envolve as práticas e discursos neoliberais na produção de formas de governamentalidade por meio de processos heterogêneos apoiados na importante genealogia e arqueologia que faz destes mecanismos FOUCAULT (2004a e 2004b). O autor francês indica, já nos anos 1970, um conjunto de práticas e teorias com fortes repercussões nos governos daquilo que ele chama de arte da governamentalidade neoliberal. Entender a emergência das teorias e práticas neoliberais é importante para compreender o meio, a norma e o quadro que implica uma "política de sociedade" e não somente a economia. Os neoliberais quiseram e conseguiram em contextos e situações históricas diversas e de maneira mais ou menos intensa impor uma agenda de governo fundada na concorrência, no indivíduo empresa e no controle social por meio das normas e da inscrição na legislação e no interior do Estado de seus preceitos (LAVAL,

\footnotetext{
${ }^{3} \mathrm{O}$ teaser corresponde a um recurso de propaganda utilizado para divulgação de produtos e atividades ao público em geral, mas, sobretudo, aos interessados na aquisição dos mesmos.
} 
2018; DARDOT e LAVAL, 2017). Isto pode lançar uma luz nova sobre o porquê de os mecanismos econômicos neoliberais serem persistentes e perenes nas sociedades ao redor do mundo e voltarem com força no Brasil atualmente. Procuraremos inserir o grupo Petrobras neste debate e relacioná-lo, por outro lado, a uma situação políticoeconômico-territorial, e de soberania, de transformação das relações econômicas na conjuntura de uma nova onda ou rodada neoliberal (BRENNER, PECK, THEODORE, 2012; WERNER, 2019).

O artigo traz, além dessa introdução e das considerações finais, quatro seções: a primeira aborda as questões conceituais ligadas ao neoliberalismo e à soberania do Estado e da nação; a segunda da privatização do setor petrolífero brasileiro; a terceira trata da privatização do grupo Petrobras propriamente dito e a quarta seção aponta uma breve discussão sobre o enquadramento pelas leis e o direito dos processos de privatização do setor.

\section{Neoliberalismo e soberania}

Quando nos referimos ao neoliberalismo estamos adotando as análises finas realizadas por Foucault no curso Nascimento da biopolítica, proferido em 1978-1979 e publicado tardiamente em 2004 em sua versão original (FOUCAULT, 2004b). Foucault nos revelava, há quarenta anos, aspectos do neoliberalismo que divergem das acepções críticas correntes e dominantes até hoje no meio acadêmico.

O que Foucault demonstrou é que o neoliberalismo não é uma simples "radicalização" dos preceitos liberais anteriores que se apoiavam numa "liberdade de mercado" e de concorrência sem freios que seriam "naturais" no capitalismo. Na verdade, o neoliberalismo é uma invenção teórica, institucional e política, fundada na prática de governo agindo sobre a subjetividade dos indivíduos, que toma apoio no liberalismo anterior, mas que transforma o curso do capitalismo.

Em primeiro lugar, o neoliberalismo não defende uma ação desregrada da economia onde o Estado não deveria intervir, como comumente se acredita; ao contrário, há no 
neoliberalismo uma defesa do intervencionismo do Estado por meio da "Formalização da sociedade sob o modelo da empresa" e de uma "Redefinição da instituição jurídica e das regras de direito" (FOUCAULT, 2004b: 165-166). O neoliberalismo se pensa como uma ordem econômico-jurídica e se inscreve conceitualmente numa linha de filiação que remonta à Max Weber, e que se situa, como indica Foucault, no nível não de forças de produção, mas das relações de produção. Ou seja, não se trata de um debate sobre a busca de um fundamento essencial do valor no sentido das análises marxistas dominantes ou na identificação de Um capital que seria o mesmo ao longo de sua evolução e que estaria submetido às crises de acumulação. Trata-se, para ele, de repensar as relações sociais e as instituições de direito a partir de uma norma que seria universal, a empresa, fundando-se, para isso, na concorrência como elemento das relações econômicas e sociais, transformando, de uma certa maneira, teoricamente, o próprio trabalho em capital, os famosos "capitais humanos" que serão desenvolvidos pela escola de Chicago.

Os neoliberais, em particular os ordoliberais alemães, segundo Foucault, têm como ponto central que o aspecto econômico é um conjunto de atividades reguladas a partir de regras que tem níveis, formas, origens e cronologias distintas. Essas regras podem ser da ordem de um habitus social, de uma prescrição religiosa, ética, corporativa e, também, de uma lei.

Foucault demonstrará que o "sistema" neoliberal, segundo os autores alemães:

É um conjunto complexo que compreende processos econômicos segundo os quais a análise econômica propriamente dita diz respeito a uma teoria pura e a uma formalização, como por exemplo os mecanismos de concorrência, mas esses processos econômicos somente existem realmente na história na medida em que um quadro institucional e regras positivas Ihe dão suas condições de possibilidade (FOUCAULT: 169, nossa tradução).

Foucault mostra-nos como a questão das regras e das normas, das leis e do direito, em última instância, têm um papel fundamental na formação e gênese do capitalismo. A questão institucional e do direito é resgatada pelos neoliberais como um problema 
político central para reinventar o capitalismo e para a sobrevida do sistema como um todo. Assim, o capitalismo que se conhece não seria dedutível da única figura possível e necessária da lógica do capital e da acumulação do capital, mas, visto do ponto de vista histórico, ele tem suas singularidades e as transformações institucionais e econômicas abrem diante dele um campo de possibilidades (FOUCAULT, 2004b: 170).

Os ordeoliberais - neoliberais que tiveram um papel central na difusão dessas teses desde os anos 1930 e do Colóquio Walter Lippman, realizado em Paris em 1938 e analisado por Foucault em seu curso - vão então procurar demonstrar que a lógica do mercado concorrencial era possível e não contraditória, ela não levaria à construção inexorável de monopólios e a crises sistêmicas do capitalismo e, em decorrência disso, para que essa teoria da concorrência pura funcionasse, se inventa um novo funcionamento institucional para ultrapassar os impasses nos quais o capitalismo frequentemente desagua.

A partir dessas perspectivas da empresa como unidade fundamental da sociedade, da concorrência como modus operandi e da intervenção jurídica como quadro de ação no jogo econômico, buscou-se inventar um outro capitalismo com um mínimo de intervencionismo econômico e um máximo de intervencionismo jurídico, nas palavras de FOUCAULT (ibid: 172). Invertendo a fórmula marxista banal de que a economia é sempre aquilo que escapa à consciência dos historiadores, Eucken, um teórico ordoliberal citado por Foucault, escreveu que o que seria o inconsciente dos historiadores, e dos economistas, é a instituição. Assim, se propõe uma ordem social economicamente regulada sobre a economia de mercado e enquadrada pela inovação institucional por meio da invocação do "Estado de direito" (FOUCAULT: 174-176).

Esse Estado de Direito deveria ser todo o contrário daquilo que os Estados interventores na economia fazem, pois ele é, segundo Hayek citado por FOUCAULT (ibid: 177-178), contrário a qualquer planejamento econômico, qualquer intervenção do Estado na economia, seja de maneira direta por uma empresa estatal ou de economia mista, seja por meio de uma intervenção indireta nos processos econômicos com medidas corretivas do rumo da economia. Hayek defende que o Estado deve formular "medidas 
de caráter geral formais e não deve propor um fim particular" para essas medidas (ibid: 178); a lei deve ser concebida com regras fixas e nunca ser corrigida em função dos efeitos produzidos, deve definir um quadro fixo onde os agentes econômicos decidem em toda liberdade, pois o quadro não deve ser mexido. Essa lei formal deve ligar tanto o Estado como os agentes econômicos, o governo devendo se submeter à regra da lei o Estado, ele ainda diz, deve ser cego aos processos econômicos, não deve procurar saber tudo que envolve o conjunto de fenômenos econômicos (HAYEK citado por FOUCAULT: 178). Aqui nos lembremos dos mantras repetidos diuturnamente pelos economistas ortodoxos sobre as regras de déficits fiscais, controle da inflação, respeito dos contratos, fazer jogar a concorrência, o Estado sair da economia, etc.

A economia é um jogo e a instituição jurídica que enquadra a economia deve ser pensada como uma regra do jogo. Assim, resume Foucault, na pretensão dos neoliberais sobre o capitalismo, ele seria composto de "um jogo de empresas reguladas no interior de um quadro jurídico-institucional garantido pelo Estado. [E seria essa] [...] a forma geral do que deve ser o quadro institucional num capitalismo renovado" (ibid). Desse modo, as regras do jogo econômico são o modelo para regras sociais e as regras sociais enquadradas pelo direito são a condição para a realização da concorrência no mercado entre as empresas. Enquadra-se pela lei as regras e normas do mecanismo competitivo da produção, da distribuição e da realização. Se define, dessa forma, a Lei e Ordem: “o Estado, a potência pública, somente intervirá na ordem econômica sob a forma da lei, e é no interior dessa lei que poderá aparecer alguma coisa que é uma ordem econômica que, ela, será ao mesmo tempo o efeito e o princípio de sua própria regulação" (ibid: 179). A lei, o direito, como quadro que é a condição de possibilidade da emergência da concorrência "pura e perfeita" definida por meio de uma análise econômica "rigorosa", o direito sendo construído como intervenção política e, portanto, do poder, vai replicar na esfera institucional os procedimentos concorrenciais entre interesses individuais que por sua vez serão a causa e a consequência da ordem econômica.

Baseado numa definição universal do Estado de Direito fundado na regulação da concorrência entre unidades sociais que são as empresas, no sentido amplo onde todos 
os indivíduos podem ser empresas e no sentido estrito de uma empresa como instituição, se impediria o intervencionismo econômico dos Estados que seria o motivo principal do surgimento dos monopólios e dos impasses do capitalismo. Assim, o problema do capitalismo não é a concorrência e a existência das empresas, mas a intervenção do Estado que promoveria privilégios e facilitaria os monopólios e levaria fatidicamente ao colapso do sistema. Para resolver isso se propõe um Estado de Direito formal que enquadraria a concorrência como motor do "progresso econômico" que resolve os dilemas socias por meio da autoregulação dos preços.

Esse "sistema" econômico-institucional, econômico-jurídico, sem proeminência de um dos elementos sobre o outro, numa espécie de causação circular, leva necessariamente, como indica Foucault, ao crescimento da demanda de intervenção judiciária, uma vez que aumentam as ocasiões de conflitos de interesses entre as partes e a necessidade de intervenção de um árbitro se faz presente. Pois, se o neoliberalismo invoca o fato que a lei deve ser a regra de um jogo onde cada um na disputa da concorrência como indivíduo- empresa é rei, faz com que o poder estatal judiciário adquira uma autonomia e uma importância novas que não se reduzem a uma simples aplicação da lei.

Foucault nos diz que nessa sociedade liberal o verdadeiro sujeito econômico não é o homem da troca, o consumidor ou o produtor, mas a empresa que não é somente uma instituição, mas uma certa maneira de se comportar no campo econômico segundo a forma da concorrência e em função de projetos e de objetivos próprios a cada um. Pois bem, nessa sociedade de empresas mais a lei vai deixar aos indivíduos a possibilidade de se comportar como eles queiram na forma da livre empresa, mais se desenvolverá na sociedade formas múltiplas e dinâmicas característica da unidade empresa, mais fricções, conflitos e litígios diversos surgirão entre essas unidades e mais necessidade de intervencionismo judiciário e de arbitragem das regras do jogo (ibid: 181). Assim, teremos menos funcionários administrativos que realizariam os controles nos ministérios e que fariam em outro regime os planos econômicos e, por outro lado, teremos mais instâncias judiciárias, mais juízes, etc. Ropke, outro economista ordoliberal alemão, escreve que "convém fazer dos tribunais, mais que no passado, os 
órgãos da economia e de lhes incumbir de missões que eram confiadas às autoridades administrativas" (apud FOUCAULT: 181). A justiça é assim erguida como um serviço público omnipresente. O que, no caso recente do Brasil, permitiu uma relativa autonomização de parcelas consequentes da instituição judiciária e da Procuradoria da República, que deixaram de lado toda isenção esperada de um árbitro para utilizar o poder judiciário como poder político e partidário.

Em resumo se pretende em um "novo quadro institucional" do Estado de Direito impedir as tendências centralizadoras e monopolistas imanentes à sociedade capitalista, mas que não seriam a lógica do capital propriamente dito, pois elas são devidas a tendências institucionais e ligadas às lutas de poder que levam a esses monopólios. Desse modo, teorizou-se uma economia concorrencial pura que, pelo interesse, regularia os indivíduos-empresas por meio de um enquadramento formal e institucional do direito que resulta numa prática institucional.

\subsection{Entre sociedade da soberania e sociedade da governamentalidade}

Esse processo da transformação do poder judiciário, das leis, normas e regras, em breve, da governamentalidade no neoliberalismo, vem de uma longa mutação e Foucault retraça sua genealogia nas relações e disputas de poder, verdadeiras guerras no entorno e dentro do Estado e dos governos que se constituíram no ocidente europeu (FOUCALUT, 2011 [1973]). Essa importância dada pelos neoliberais ao quadro jurídico e legal, ao direito, revela algo de fundamental que está associado a uma sociedade da norma e da normalização, à inoculação nos sujeitos de formas de práticas que se fundam nas regras de observação da população como conjunto "vivente" dos homens e sobre os quais se operariam os interesses associados com a empresa.

Com o neoliberalismo hegemônico contemporâneo, conforme descrevemos anteriormente, se acentuam os processos de governo dos indivíduos por meio da gestão das populações e de seus interesses que nesse caso seriam a decisão sobre o ganha e perde do cidadão empresa, o que poderíamos denominar, grosso modo, como sendo 
uma das formas da biopolítica, que são refletidos nas normas e nos meios de vida e que são enquadrados por uma legislação, pelo direito.

Para resumir, a partir de DARDOT e LAVAL (2020), poderíamos dizer que a noção de governo, e por derivação a noção de governamentalidade dos sujeitos, se aplica aos homens como população, como "viventes" - as leis seriam como táticas que antes procuram dispor que impor um processo. Assim a sociedade atual e o neoliberalismo, diriam respeito a uma sociedade da normalização que está articulada ao poder da lei e ao poder jurídico por meio da segurança que operam pelo interesse, parecendo haver um deslocamento gradual no interior do Estado e dos governos das esferas do poder executivo e legislativo, propriamente ditos, em relação ao poder judiciário. Nessa sociedade, a regra, a norma, a lei, funcionam fundadas sobre um saber: no caso em análise, as leis da economia e são enquadrados por uma legislação que não se restringe aos territórios nacionais e que, hoje, frequentemente são transnacionais, como os tratados e as leis de instituições internacionais e, também, americanas, como o Patriot Act adotado depois do atentado à torres gêmeas de Nova lorque em 2001 e que invoca o combate ao terrorismo e à corrupção como pano de fundo para investigar empresas que negociam nas bolsas americanas ou que tem qualquer tipo de atividade ligada aos Estados Unidos, permitindo, assim, se usar essa lei para operações de guerra contra empresas concorrentes de empresas americanas.

Já nas sociedades de proeminência da soberania, a lei é a regra como vontade do soberano, individual ou coletivo; a soberania supõe sujeitos de um território que obedecem a um soberano, a lei como vontade de um soberano e não como práticas institucionais que procuram dominar os poderes dos governos submetendo-os aos mercados no neoliberalismo.

O Neoliberalismo, nesse sentido opera uma transformação do Estado e dos governos, ultrapassando os limites dos Estados nacionais. A soberania com o tempo se transforma, passando do modo teológico-ontológico da justificativa do poder das monarquias do passado para, no mercantilismo, fundar o incremento da riqueza nacional e controle das fronteiras em busca de um "equilíbrio" nas rivalidades entre os Estados. Transforma-se 
ainda no século XVIII e XIX, com o advento do liberalismo do laisser faire e da livre concorrência entre nações, e chega até o presente com a ascensão do neoliberalismo do indivíduo-empresa. Mas essa soberania - aparentemente, reduzida nas teorias neoliberais que invocam o jogo da concorrência entre empresas e territórios-empresas - é ativada de fato como forma de "regulação" e de enquadramento dos interesses neoliberais. Desse modo, DARDOT e LAVAL (2020) dizem que a soberania, malgrado o fato de Foucault ter demonstrado sua transformação e que ela, talvez, pudesse ser superada por outras formas de mutação de governo, se mantém como uma figura importante, pois segundo eles o "Estado absoluto moderno coloca suas exigências à maneira de uma igreja", tem uma força simbólica como pessoa pública, teria uma "alma". Donde a duração do Estado como força enquadradora e, também, como força política de controle, pois os neoliberais necessitam de um Estado forte, malgrado o apelo que fazem, como vimos, ao "Estado de Direito", o que parece mais uma ficção, pois os Estados utilizam os mecanismos da soberania para se colocar ao serviço do capitalismo. As escolhas das políticas econômicas pelo neoliberalismo se adequam cada vez menos aos preceitos do "Estado de Direito" invocado por Foucault em relação aos neoliberais e são cada vez mais associadas a processos autoritários de imposição das regras e normas da concorrência e do Estado social mínimo.

Essa situação encontrou sua aplicação primeira no Chile de Pinochet e seus Chicagos Boys que tiveram uma larga influência nas políticas de guerra social que destruíram boa parte das políticas públicas e sociais chilenas anteriores, instaurando políticas neoliberais fundados na "soberania da nação" chilena que não se confundia na Constituição outorgada pelos militares em 1980 com a "soberania popular". Os resultados catastróficos dessas políticas se fizeram sentir mais de quarenta anos depois, nas recentes manifestações no país que levaram à aprovação de um referendum que definiu a elaboração de uma nova Constituição para substituir aquela herdada da junta militar. Hayek inclusive marcou seu apoio ao governo ditatorial de Pinochet em 1981, dizendo que preferia "um ditador liberal a um governo democrático donde está ausente o liberalismo" (apud DARDOT, GUÉGUEN, LAVAL SAUVÊTRE, 2021: 31). Claro, o "liberalismo" a que ele se refere é o econômico. 
Para Dardot e Laval, a soberania é indissociável da dominação e do Estado moderno e há um impasse na categoria de soberania, pois ela é reivindicada tanto pela esquerda, como pela direita e a extrema-direita do espectro político. A soberania envia à noção do latim de Dominion, de dominação, de um soberano sobre um território. Assim, poderíamos pensar que para além da dominação por meio do interesse e da busca do consentimento dos dominados que foi teorizada por Max Weber, há, por meio da soberania, uma dominação pela autoridade nos tempos contemporâneos. A soberania, nos dizem Dardot e Laval, se transmutou com o passar do tempo no Estado moderno por meio da administração do Estado, pela instituição, instaurando uma dominação impessoal e permanente (DARDOT e LAVAL 2020: 8-10).

Em efeito, os autores demonstram que o conceito de soberania é intrinsecamente associado ao Estado moderno ocidental europeu que se alastrou pelo mundo por meio da colonização. Estamos no ponto em que a manutenção do Estado é preponderante sobre os outros processos políticos exercidos pelos representantes eleitos e, que se supõe, responderiam pelos interesses coletivos nas democracias liberais. Ora, como dizem, "a dominação do Estado, que se exerce por seus representantes, pressupõe a superioridade do Estado sobre seus representantes" (DARDOT, LAVAL, 2020: 19). Ou seja, a soberania sobre a qual se baseia inúmeras defesas do Estado moderno é na realidade uma forma de assegurar a manutenção do próprio Estado. O Estado-nação moderno é "um centro político que se atribui o monopólio da produção da lei às quais cada um deve obedecer sobre um território" (ibid: 20). Apesar de o Estado moderno não ter mais um controle estrito sobre seu território em função "da interdependência generalizada e a intervenção de novos atores não estatais (ONGs, multinacionais, etc.)" (ibid: 19), ele continua sendo um modelo essencial nas relações internacionais de "independência de cada Estado em relação aos outros Estados". Havendo uma articulação entre uma arquitetura institucional interna e externa do poder estatal fundada sobre a soberania:

Sobre o plano interno, a soberania é uma potência de querer e de comandar tal que ela não suporta nenhum veto da parte de um grupo 
ou de uma instituição; no plano externo, a soberania se define como uma independência absoluta em relação a qualquer outra entidade política (ibid: 20-21).

O Estado assim é "mestre em sua casa", o território nacional é o domínio do Estado que modula e se deixa permear pelos fluxos econômicos neoliberais. O Estado soberano é dominação, é o exercício de uma autoridade suprema sobre um território apropriado por uma pessoa pública que é seu domínio exclusivo (ibid: 21). O Estado tem a supremacia sobre a propriedade exclusiva dos meios políticos e administrativos de dominação da população, pois não há, nessa perspectiva, poder acima do poder do Estado, e esse poder superior a todos os outros está ligado à "posição eminente daquele que é proprietário da coisa pública" (ibid: 22).

O que Dardot e Laval nos dizem é que com a ideia de soberania há uma grande confusão entre a soberania do povo, a soberania da nação e a soberania do Estado que favorece a manutenção do poder do Estado por cima de todos os poderes.

(...) "a soberania do povo" como princípio constitucional de legitimação de representantes do povo significa outra coisa que o conceito original e fundamental de soberania do Estado. Ou mais exatamente ela não diz respeito ao mesmo registro. No primeiro caso, se trata do exercício legítimo de um poder regulado segundo os procedimentos legais de nominação (princípio dinástico ou eletivo); no segundo caso se trata das prerrogativas efetivas de uma pessoa pública dotada de autoridade suprema. Os detentores do poder são naturalmente muito interessados a justificar o segundo sentido pelo primeiro, segundo uma prestidigitação absolutamente essencial ao funcionamento político dos Estados antigos e modernos. (DARDOT e LAVAL, 2020: 22).

Assim, a confusão entre essas duas noções de soberania tem consequências consideráveis para as democracias liberais representativas atuais, pois a "independência em relação a todo poder exterior constitui a base mesma da ideia de autodeterminação de uma nação, o que tem a vantagem de ocultar a outra face, aquela da soberania do Estado sobre a população." (ibid: 23). Os autores citam Wendy Brown para quem esse é 
um dos principais "paradoxos da soberania": "o nome da soberania designa ao mesmo tempo um poder absoluto e uma liberdade política. É assim que a dimensão da dominação da soberania estatal foi diluída e mesmo recoberta pelo discurso de autolegitimação dos "representantes políticos." (ibid: 23).

Esse debate nos leva à questão relativa à aparente cisão entre uma visão soberana em relação à Petrobras por aqueles que nos quadros do Estado nacional defendem a empresa como devendo ser controlada pelo Estado e servindo aos interesses públicos, e aqueles que defendem uma "outra soberania", aquela do Estado autoritário como forma de legitimar o neoliberalismo. As duas visões estão no mesmo campo, ou seja, o da soberania do Estado, esse ente abstrato e concreto, ao mesmo tempo que se supõe estaria acima de todos interesses. Porém, como sabemos, quem ocupa o Estado tem seus interesses próprios que se servem da crença no Estado como inevitável e que estaria acima de todos: a pátria acima de todos, como indica o bordão do bolsonarismo. Não queremos dizer, com isso, que essas posições se equivalem e que não exista "projetos nacionais" que se proponham a ser democráticos e que incluam os interesses comuns e que muitas intervenções estatais fizeram avançar as conquistas sociais dentro do Estado e por meio do Estado, o problema é como a "soberania" deve ser abordada e enfrentada como um dos pilares dos Estados. Para além do Estado ser um ente globalizante e totalizante de relações de poderes, que compõem a trama das relações sociais como o invocava Foucault, Dardot e Laval invocam um Estado que perpetua a coação e a repressão e que exerce a guerra a seus cidadãos. O conceito de liberdade política como contrapartida do feixe de relações de poderes cristalizados no Estado é secundarizado e na atual fase neoliberal predomina o Estado permanente de guerra civil.

Assim, temos duas concepções de soberania que podem se confundir, mas que são aparentemente diferentes, de maneira que a invocação da soberania por aqueles que são contra a privatização da Petrobras acaba não sendo levada em conta pelo governo, pelo poder judiciário e pelo parlamento que são habitados pelos preceitos de uma soberania neoliberal e muitas vezes autoritária. Porém nos questionamos se as duas 
posições não acabam comungando de uma mesma idealização em relação a um ente público estatal que tem o domínio sobre todos e está acima de tudo, o que somente contribui para uma mistificação da soberania. Abrindo-se, assim, uma armadilha para as posições de esquerda ou "progressistas" que defendem a Petrobras sob controle do Estado em nome da soberania, pois essa posição pode acabar de certa forma solidificando o conceito de soberania nos espíritos, sem interrogá-lo, fazendo com que todos estejam no mesmo campo genealógico e arqueológico do sentido do soberano como justificativa do poder e do domínio do Estado e inclusive, em muitos casos, sendo, voluntária ou involuntariamente, a favor de uma solução autoritária para, eventualmente, manter a empresa sob as asas do Estado. Porém, não se questiona, ou pouco, o fato de que se poderia colocar a empresa sob o controle de seus trabalhadores e dos cidadãos, sem a necessária mediação do Estado, a retirando do mercado de ações, de competição e a subtraindo aos processos capitalistas.

Nas próximas seções abordaremos a privatização do setor petrolífero brasileiro e a privatização do grupo Petrobras, o que torna o controle dos impactos sobre os interesses coletivos e comuns aos quais o setor e o grupo estão associados ainda mais difícil e complicado em relação ao controle do Estado. Isso porque um controle pelo Estado permitiria uma certa influência política positiva, no sentido do interesse coletivo, dos governos sobre a empresa a depender de quem ocupa a posição de governante, apesar dos senões que invocamos precedentemente sobre a noção problemática de soberania.

\section{A privatização do setor petrolífero brasileiro}

É a partir de 1997, durante os governos de Fernando Henrique Cardoso e da invasão vitoriosa das teses neoliberais nas hostes do Estado brasileiro, que foi aberta uma possibilidade para a privatização de parcelas de diferentes segmentos das atividades petrolíferas no Brasil, por meio da Lei 9.478, conhecida como a lei do petróleo. Essa lei de 1997 instituiu, dentre outras coisas, a possibilidade de participação de outras empresas no segmento de exploração. A partir de então grupos nacionais, mas 
sobretudo internacionais, passaram a adquirir concessões de blocos exploratórios de petróleo ofertados e regulados por meio da então recém criada Agência Nacional do Petróleo $(\mathrm{ANP})^{4}$. Além disso, a referida lei deixou em aberto a participação de setores privados no transporte de óleo e gás e no refino ${ }^{5}$.

No que se refere à participação no segmento upstream, a ANP passou a organizar as ofertas de blocos exploratórios por meios de leilões. Inicialmente, na forma de regime de concessão que se caracteriza como sendo uma modalidade de contrato onde os poderes públicos realizam um processo concorrencial no qual um determinado agente econômico demonstre capacidade para exercer seu desempenho na exploração e produção sob sua responsabilidade em prazo determinado. De 1999 até 2019 foram realizadas 15 rodadas de leilões de blocos sob o regime de concessão e 04 rodadas de leilões de campos maduros nas diferentes bacias sedimentares brasileiras. Vale ressaltar que os campos maduros são compreendidos como sendo os campos em que a produtividade de petróleo ou gás vem diminuindo em função do tempo de exploração.

O recurso petróleo é, dessa maneira, visto não como estratégico para procurar se pensar uma política de "desenvolvimento" que visasse atender tanto aos interesses sociais, quanto a uma política que valorizasse a transição energética, buscando reduzir gradualmente o consumo de petróleo e utilizar parcelas dos recursos do próprio petróleo para promover investimentos em energias limpas. Vê-se o recurso como um ativo econômico passível de exploração intensa e internacionalizada e que deveria sair das mãos do Estado, isso legitimado por normas neoliberais que engendraram leis oriundas das relações de poder que se estabeleceram no jogo político interno onde se buscou enquadrar o Estado sob um quadro de normas/leis que favorecessem a competição e a internacionalização do setor. Aceitou-se, assim, adentrar num regime de "leilões", considerando o petróleo como num mercado qualquer. Processo que será completado com o ingresso da empresa na bolsa de valores de New York em 2001 e o gradual recurso ao "mercado" e ao lançamento de ações que farão com que o controle

\footnotetext{
${ }^{4}$ A ANP foi criada juntamente com a lei no 9.478/1997.

${ }^{5}$ Ver artigos 53 e 56 da lei 9.478/1997.
} 
acionário da companhia pelo Estado se reduza gradualmente, em particular a partir de 2018. O percentual de ações de controle da empresa detido pelo Estado brasileiro, incluindo as participações da Caixa Econômica, FGTS e BNDES, passou de 66,2\%, em 2018, para 50,2\% em 2020. A participação do capital internacional no mesmo período na empresa cresceu quase quatro vezes, passando de $11 \%$ para $39 \%$ das ações ordinárias. O Estado continua soberano e por meio dessa soberania garante a entrada da empresa na bolsa e sua privatização. Voltaremos mais adiante a comentar sobre os efeitos deletérios da definição da política de privatização gradual da empresa a partir de 2016, em função da prioridade dada à remuneração dos acionistas em detrimento do investimento e ao se adotar uma explicita política de retirada do Estado das atividades econômicas. Mas, antes, retornemos a 2003, início dos governos do Partido dos Trabalhadores e da concretização da descoberta da nova fronteira do pré-sal no mar que permitiram a ampliação das "reservas" de petróleo e gás no país.

As reservas provadas no Brasil eram, em 2017, de cerca de 12,8 bilhões de barris e as reservas da Petrobras, em 2020, eram de 8,8 bilhões de barris ${ }^{6}$, mas as reservas estimadas exploráveis prováveis do pré-sal que foram descobertas e consolidadas a partir de 2005, sobretudo na Bacia de Santos, que calculamos a partir de diferentes autores e metodologias, estaria situada entre 44 a 83,7 bilhões de barris. Esses cálculos foram realizados a partir da estimativa de $25 \%$ a $50 \%$ de óleo recuperável aplicados sobre o volume de 176 bilhões de barris "in place" estimados e ainda não "comprovados" pela efetiva produção e consolidação dos campos - a Petrobras detém, segundo nossos cálculos, ainda $67 \%$ dessas reservas nos diferentes regimes de exploração, o que equivaleria para a empresa entre 29,4 e 58,9 bilhões de barris a serem produzidos. $^{7}$

Assim, a partir da descoberta de reservas importantes no pré-sal, buscou-se instituir novos marcos regulatórios sobre os contratos de exploração e produção que indicavam

\footnotetext{
6 Disponível em https://clickpetroleoegas.com.br/petrobras-informa-8816-bilhoes-de-barris-depetroleo-com-reservas-provadas-em-2020. Acesso em fev. 2021.

${ }^{7}$ Ver sobre essas estimativas ZANOTELLI et al (2020), SAUER e RODRIGUES (2016: 185-229), LAIER (2019) e MACHADO (2018).
} 
uma vontade de alterar os leilões do petróleo. Procurou-se garantir para a Petrobras, apesar de uma série de limitações da legislação, um domínio relativo sobre a exploração e produção, muitas vezes em associação com grandes multinacionais no desenvolvimento de tecnologias e da exploração. Essas novas formas de contrato foram a Cessão Onerosa e o Regime de Partilha de produção que têm seus limites, pois continuavam, em particular para o regime de partilha, a "leiloar" os blocos de petróleo e de gás, bem como se procurou financiamentos no mercado internacional que tornaram a Petrobras ainda mais dependente de capitais externos.

O regime de Cessão Onerosa, interessante do ponto de vista de uma política proativa econômica no setor de energia do Estado e da Petrobras, foi estabelecido pela lei 12.276 de junho de 2010, ele regulamenta que a União autoriza a ceder diretamente a Petrobras, em troca de uma remuneração por parte da empresa, os blocos de petróleo, dispensando-os, assim, das licitações que são obrigatórias nos contratos de concessão que até então eram predominantes. Assim a empresa pôde exercer as atividades de pesquisa e exploração de petróleo em áreas não concedidas localizadas numa determinada área delimitada pelo polígono do pré-sal, até o limite de 5 bilhões de barris de petróleo e gás natural. Nessas áreas, a Petrobras arcaria com todos os custos e assumiria todos os riscos de produção (LEÃO, 2018).

Por sua vez, os contratos de Regime de Partilha, de modo geral, correspondem a uma forma de contrato estabelecido pela lei 12.351 de 22 de dezembro de 2010 para áreas do pré-sal e outras tidas como estratégicas. Esse regime envolve a criação de um Fundo Social e da empresa Pré-sal Petróleo S.A (PPSA) ${ }^{8}$ que é responsável pela gestão dos excedentes de petróleo (excedente óleo) acordados nos contratos com as petroleiras e que devem ser "pagos" ao Estado como contrapartida pela cessão dos blocos exploratórios. Nessa nova regulamentação, exigiu-se que a Petrobras fosse operadora

\footnotetext{
${ }^{8}$ A Pré-Sal Petróleo é uma empresa vinculada ao Ministério de Minas e Energia. Sua missão é gerir os contratos de partilha de produção, representar a União nos Acordos de Individualização da Produção e comercializar o petróleo e gás do governo federal. A PPSA é gestora de 17 contratos de partilha de produção. Esse regime vigora no Polígono do Pré-Sal e em áreas estratégicas, como as Bacias de Campos e Santos, desde 2010. (Agência Brasil, 15/12/2020 disponível em https://agenciabrasil.ebc.com.br/economia/noticia/2020-12/excedente-de-oleo-do-pre-sal-chega-74na-producao-de-outubro. Acesso em fev. 2021).
} 
dos contratos e com uma participação mínima nos mesmos de $30 \%$ sobre as áreas licitadas. Definiu-se como critério principal do leilão dos blocos a parcela de petróleo excedente que os consórcios/petroleiras destinariam para a União e que é gerida pela PPSA (LEÃO, 2018). Assim, as companhias/consórcios vencedoras são aquelas que oferecem à União, a partir de um percentual mínimo fixado, o maior percentual de excedente em óleo e gás. Esse excedente é a parcela da produção de petróleo e gás destinada à União pelo contratado, segundo critérios definidos em contrato e é resultante da diferença entre o volume total da produção e as parcelas relativas ao custo em óleo na produção do petróleo. ${ }^{9}$

A partir de 2016, depois de uma série de ações políticas escudadas na constatação de corrupção em alguns setores da Petrobras e na realização de cooperações internacionais ilegais com representantes de governos estrangeiros, em particular os norteamericanos, se enfraqueceu a Petrobras ${ }^{10}$, possibilitando a emergência de uma aliança neoliberal e neoconservadora que tomou de assalto o poder e que alterou o regime de Cessão Onerosa e o de Partilha estabelecidos anteriormente.

Em relação à Cessão Onerosa, houve a descoberta de um "excedente" dos cinco bilhões iniciais de barris de petróleo que pode variar, segundo as diferentes estimativas, de 6 a 15 bilhões de barris. Este excedente, foi em 2019, leiloado, pela ANP, depois de terem sido cedidos pelo Estado à Petrobras no passado. Entretanto, somente a Petrobras, por diversas razões, em particular pelo fato de ela ser a responsável pela infraestrutura de exploração dos campos, se candidatou juntamente com empresas chinesas a participar

\footnotetext{
${ }^{9}$ Parcela da produção de petróleo e gás correspondente aos custos e aos investimentos realizados pela petroleira/consórcio na execução das atividades de exploração, avaliação, desenvolvimento, produção e desativação das instalações, sujeita a limites, prazos e condições estabelecidos em contrato (BRASIL, 12.351 de 2010).

10 Sobre essas relações perigosas entre a autodenominada Operação Lava Jato e o Departamento de Estado Americano ver uma síntese dos valores das multas que desestabilizaram a Petrobras, ZANOTELLI et al (2020: 165-170). Para uma visão ampla sobre o papel que cumpriu a Lava Jato de fator de instabilidade empresarial no setor do petróleo e institucional a nível do país veja-se as matérias do Jornal The Intercept Brasil de 2019-2021 e as matérias do jornalista Luiz Nascif no Jornal GGN sobre o tema, bem como as recentes matérias em fevereiro 2021 dos grandes jornais a partir do vazamento dos diálogos dos responsáveis da operação, agora legitimados pela validação das gravações pela Polícia Federal que foram parcialmente tornadas públicas por decisão do ministro do Supremo Tribunal federal Ricardo Lewandowski.
} 
do leilão do "excedente" da área de Cessão Onerosa de Búzios, a maior descoberta de petróleo do país e, sozinha, a Petrobras adquiriu outra área, a de Itapu. Esse "excedente" ao contrato original de óleo é de fato uma extensão dos campos de 5 bilhões de barris do mesmo tipo de regime concedidos anteriormente e que deveriam ser explorados pela Petrobras. ${ }^{11}$ Mas, recentemente, se anunciou para dezembro de 2021 um novo leilão, para as áreas de Atapu e Sépia que não tinham sido adquiridas anteriormente. 0 governo reduziu os bônus que devem ser pagos por esses blocos em cerca de $70 \%$ para, assim, compensar as petroleiras internacionais pelo reembolso que elas deverão realizar dos investimentos efetuados pela Petrobras na exploração dessas áreas. ${ }^{12}$

Por sua vez, o Regime de Partilha sofreu alterações por meio da lei 13.365/2016. Dentre outras providencias, a lei retira a obrigatoriedade da participação da Petrobras como operadora e com participação mínima de $30 \%$ nos consórcios e torna a participação da companhia facultativa. Todos os blocos que serão ofertados pelo regime de partilha pela ANP a partir de então serão apresentados à Petrobras, e caberá à companhia decidir se deseja ou não participar do leilão do bloco. Nos mapas 01 e 02 podem ser visualizados os regimes de Cessão Onerosa e Partilha. Vale ressaltar que os mapas focam no polígono do pré-sal, que é a única área com mais de um regime de contrato, pois ali, além da partilha e a cessão onerosa, há também os regimes de concessão estabelecido antes das mudanças das leis entre 2010 e 2012. Nas demais bacias sedimentares do Brasil prevalece o regime de concessão estabelecido ainda em 1998. É bom lembrar que a mudança das leis depois de 2016 reduziram o percentual de nacionalização dos equipamentos e infraestruturas da exploração e produção do petróleo, demonstrando uma força dos agentes das transnacionais fornecedoras dominantes do setor sobre as orientações do Estado brasileiro a partir do ano de 2016. E ainda os governos Temer e Bolsonaro mantiveram e ampliaram o regime de isenções fiscais do setor por meio do Regime Aduaneiro Especial de Exportação e Importação de Bens Destinados às Atividades de Pesquisa e Lavra das Jazidas de Petróleo e de Gás Natural (Repetro) que,

\footnotetext{
${ }^{11}$ Ver sobre estes diferentes pontos e as manobras realizadas para tentar "liberalizar" e desnacionalizar os campos ZANOTELLI et al (2020).

12 Folha de São Paulo, 20 de abril de 2021. Disponível em www1.folha.uol.com.br/mercado/2021/04/governo. Acesso em abr. 2021.
} 
crescentemente, a partir de 2016, beneficiaram empresas "de fora" antes que aquelas sediadas no Brasil.

\section{Mapa 01: Regimes de contrato no pré-sal (1998 e 2020)}

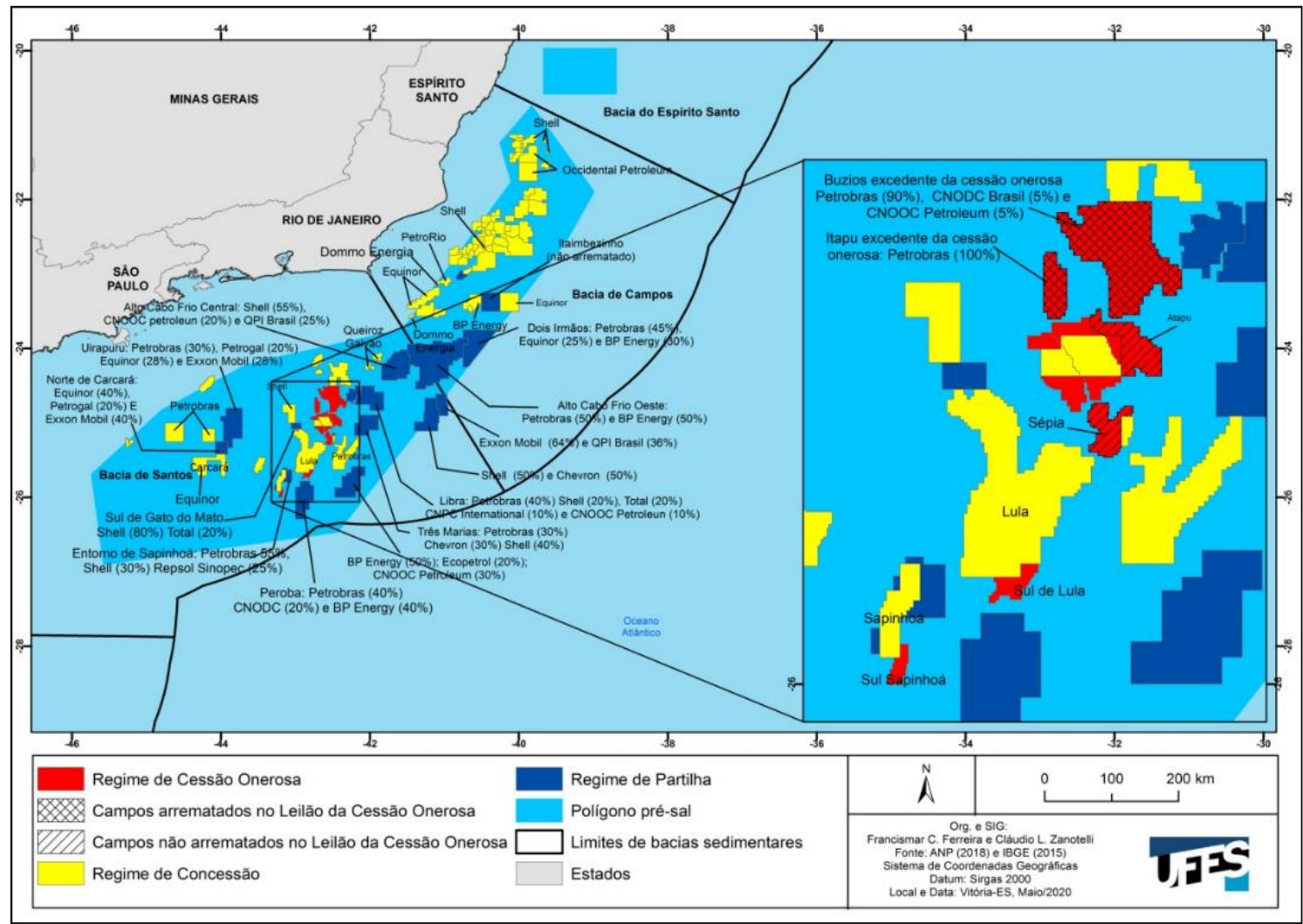


Mapa 02: Campos de produção e blocos de exploração com suas concessionárias nas Bacias de Campos e Santos segundo os leilões de concessão e de partilha

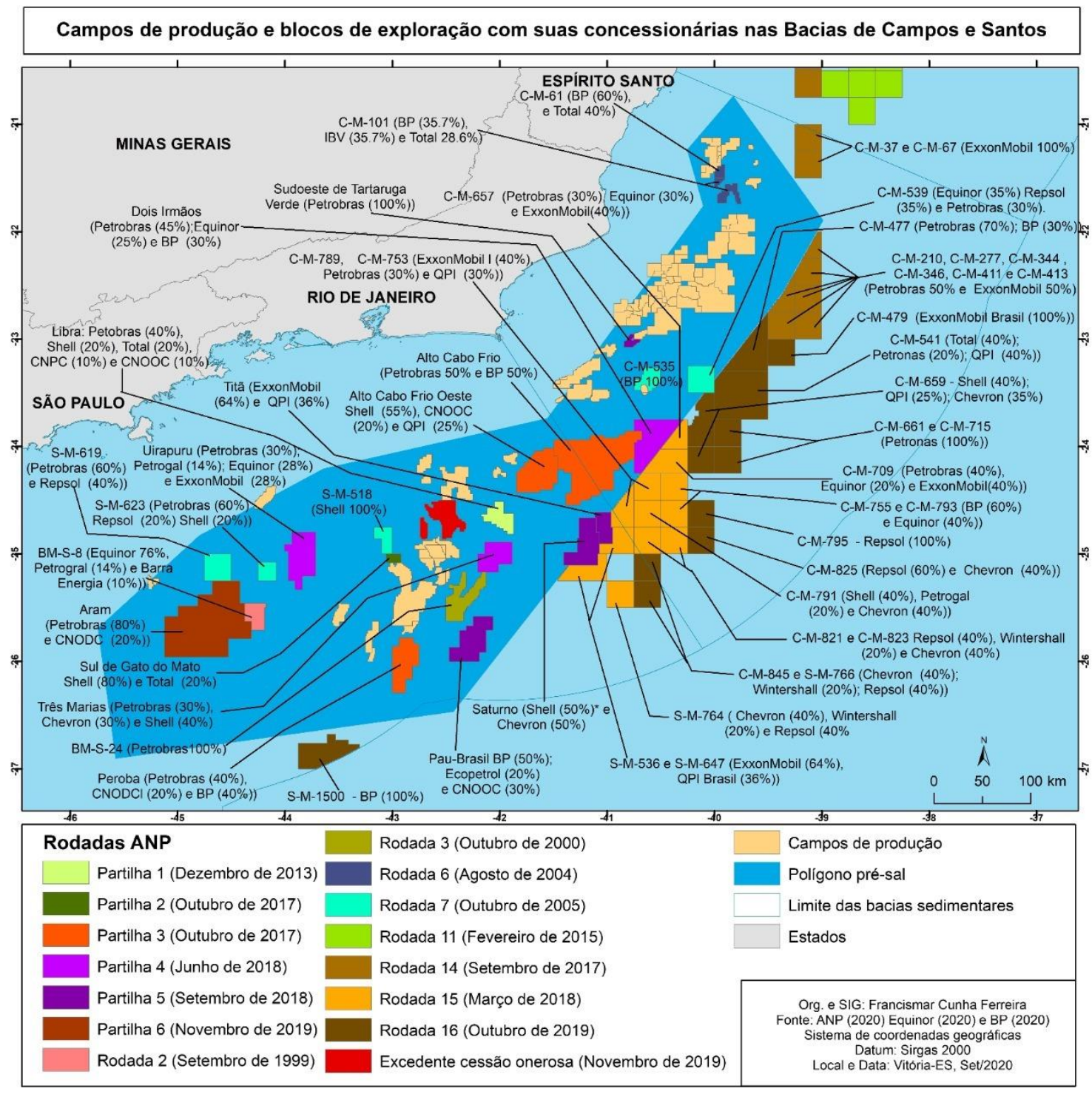

A alteração do regime de partilha e dos modos de concessão por meio de leilão do excedente óleo da Cessão Onerosa representaram uma maior abertura do pré-sal para o capital internacional. Evidentemente, desde 1998, como vimos, houve a abertura para as multinacionais na exploração e produção do petróleo, mas, de certa maneira, pelo menos na exploração e produção direta do petróleo, essa internacionalização foi contida na primeira década dos anos 2000 pela predominância no setor da Petrobras, reforçada 
pela importância dos investimentos realizados por essa última com o apoio do Estado brasileiro a partir de 2006, o que permitiu investimentos vultosos na descoberta das gigantescas reservas da camada do pré-sal. Por outro lado, pela introdução da Cessão Onerosa e do Regime de Partilha no período entre 2010 e 2013, se permitiu reafirmar o leadership da Petrobras, garantindo-Ihe a proeminência na exploração do pré-sal, mesmo se o governo do Partido dos Trabalhadores não foi tão longe como poderia se esperar em termos de reservar todo o pré-sal para a Petrobras como reivindicava, por exemplo, a Associação dos Engenheiros da Petrobras (AEPET). Assim, geralmente, as multinacionais do setor eram minoritárias e quase sempre estavam associadas à Petrobras nas grandes campanhas de exploração, partilhando com a empresa brasileira os riscos da exploração, sobretudo fornecendo parte dos equipamentos e do financiamento das campanhas de exploração e colhendo os frutos da descoberta do présal.

Entretanto, essa situação evolui rapidamente a partir de 2016, em função das modificações promovidas pelos governos de Michel Temer e de Jair Bolsonaro, que acentuaram a neoliberalização do Estado associando-a ao autoritarismo, promovendo mutatis mutandi a privatização rampante do setor e provocando uma mutação no poder soberano do Estado. Adotando uma "soberania" que se diz "nacionalista" fundada nos símbolos nacionais e no "discurso da pátria" e pregando a violência contra o "inimigo interior", excluíram efetivamente o povo dessa ideia de soberania e de nação, e se dobraram, por outro lado, aos interesses dos capitais internacionais, aprofundando os preceitos neoliberais como vimos anteriormente. Para permitir a penetração dos capitais internacionais na empresa e no setor, alteraram a regulação da exploração e produção do petróleo por meio de uma agressiva realização de leilões (Cf. Mapa 2), bem como acentuaram a venda de campos (onde já se produz petróleo) e blocos (onde se encontram as atividades de pesquisas exploratórias) para outras empresa (conforme o quadro 01) em todo o Brasil. Esse processo está sendo acompanhado da venda, muitas vezes ao arrepio da lei, de empresas controladas, de subsidiárias e das participações da Petrobras em diversas outras empresas do ramo. Desse modo, a participação das transnacionais do petróleo no Brasil, tanto nos leilões da ANP quanto no volume de 
petróleo produzido, vem aumentando continuamente. Em 2011, a Petrobras foi responsável por $91,7 \%$ do total da produção de petróleo contra $8,22 \%$ de petroleiras transnacionais e 0,08 de petroleiras nacionais privadas. Em 2019, a produção da Petrobras no total representou $74,1 \%$, enquanto que as multinacionais responderam por 24,18\% e as petroleiras nacionais privadas 1,72 (ANP, 2012 e 2020). No gráfico 01 pode ser mais bem visualizado esse processo.

\section{Gráfico 01: Produção das concessionárias que atuam na exploração de petróleo no Brasil.}

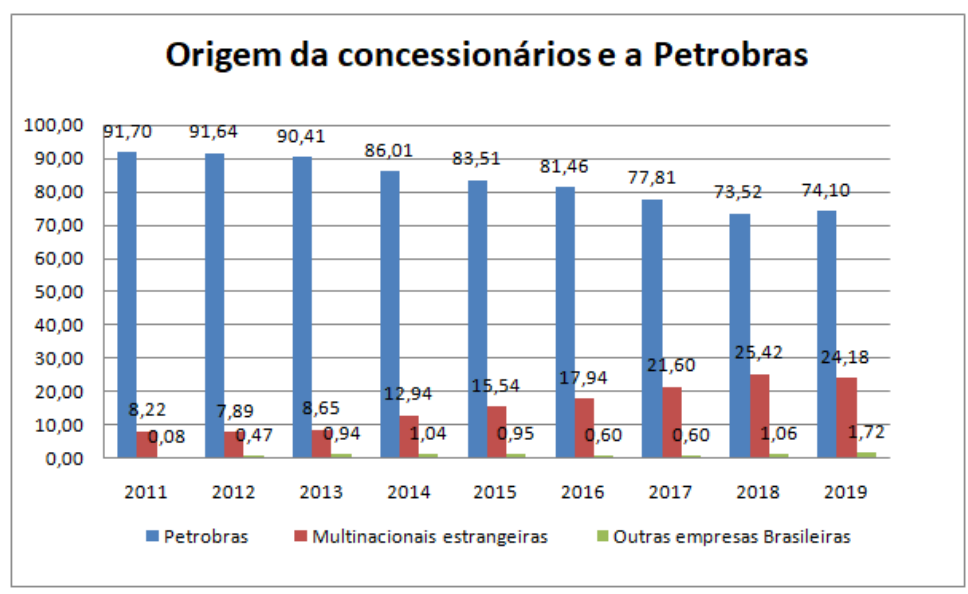

Fonte: ANP (2011 - 2020)

As companhias petrolíferas que detêm a maior parte desse volume de produção são evidentemente as grandes multinacionais do setor, a Shell (Reino Unido-Holanda), a Petrogal (Portugal), a Equinor (Noruega), Repsol (Espanha) e Sinochem (China). A participação dessas empresas e de outras transnacionais e/ou nacionais no setor petrolífero brasileiro tende a crescer de modo significativo por causa do novo quadro político-econômico que promove uma abertura acentuada do setor.

As gestões da Petrobras a partir de 2016 - após o golpe político - impulsionadas por operações políticas e geopolíticas apoiadas numa forma abusiva de exercício da "justiça" por meio do lawfare, têm implicado num movimento duplo, de desconstrução do grupo 
e de retirada do Estado do setor. Por um lado, ocorre a venda dos ativos de exploração e produção e de controladas e subsidiárias da Petrobras que leva à desintegração da empresa, tornando-a gradualmente uma mera companhia de exploração de petróleo centrada principalmente no pré-sal e na vontade de explorar o mais rápido possível as jazidas, antes que a transição energética torne o petróleo uma energia relativamente secundária. Por outro lado, ocorrem modificações das regulamentações que ampliam a participação de outras empresas na exploração de petróleo no território nacional, em especial na região do pré-sal. Abordaremos a seguir a privatização do grupo Petrobras.

\section{A privatização do grupo Petrobras}

Nesta parte, inicialmente, descreveremos a venda de blocos e de campos de petróleo pela empresa entre 2018 e 2020, para em seguida analisarmos seu desengajamento das participações e investimentos no exterior e, finalmente, demonstraremos a venda de empresas coligadas, controladas e subsidiárias, em particular do setor de gasodutos, bem como de refinarias e de empresas do setor de distribuição de combustíveis. Concluiremos com uma análise sobre as disputas de poder em volta dos processos de legitimação institucional para se desnacionalizar a empresa.

Pelo que pudemos computar e obter informações, a ordem de grandeza do valor das dezenas de ativos que foram privatizados, sobretudo entre 2017 e 2020 - muitas vezes subavaliado segundo diversas avaliações do sindicato dos petroleiros e, segundo nossas próprias observações, em relação a atividades que já estavam em muitos casos totalmente amortizadas e que eram lucrativas para a empresa - é de 45,95 bilhões de dólares até agora (Cf. Tabela 1). Esse valor correspondia a cerca de $60 \%$ do total de receita de vendas da empresa em 2019, portanto uma alienação de patrimônio que se revela em proporção às vendas anuais da empresa não tão significativo. Ademais, isso se revelará com o tempo contra-produtivo, uma vez que se abriu mão de ativos que garantiam ganhos substanciais para o grupo (como a BR Distribuidora de combustíveis) ou que reduziam seus custos (como os gasodutos que agora deverão ser alugados para 
se movimentar o gás explorado pela empresa), portanto essas vendas irão reduzir a possibilidade de receitas do grupo Petrobras e favorecem a sua desintegração vertical.

TABELA 1: Receitas com as privatizações de ativos do grupo Petrobras de 2013 a 2020

\begin{tabular}{|l|c|}
\hline \multicolumn{1}{|c|}{ Setores } & Valores em bilhão de dólares \\
\hline $\begin{array}{l}\text { Campos de produção e blocos de } \\
\text { exploração de petróleo e gás }\end{array}$ & 12,84 \\
\hline $\begin{array}{l}\text { Participações em investimentos } \\
\text { internacionais }\end{array}$ & $\mathbf{7 , 6 9}$ \\
\hline $\begin{array}{l}\text { Infraestruturas e plantas } \\
\text { industriais }\end{array}$ & 18,72 \\
\hline Distribuição de combustíveis & 6,7 \\
\hline Total & $\mathbf{4 5 , 9 5}$ \\
\hline
\end{tabular}

3.1 A privatização de campos de produção e de blocos de exploração de petróleo e gás da Petrobras entre 2016 e 2020

No quadro 01 pode-se observar as vendas de campos e blocos de petróleo, por um valor de 12,84 bilhões de dólares, o que representa cerca de 7,2\% da receita líquida e pouco mais de 14,5\% da dívida líquida da empresa, somando os anos de 2018 e 2019 (Balanços da Petrobras 2018 e 2019). A maioria foi vendida entre 2018 a 2020. Assim, em pouco tempo, a empresa cedeu sua participação majoritária em campos importantes no Présal da Bacia de Santos (lara e Lapa vendidos à Total) e vendeu blocos exploratórios promissores no mesmo pré-sal como Carcará (vendido à Equinor), além da cessão de vários campos no pós-sal e no pré-sal na Bacia de Campos, em particular uma parte de um dos maiores campos de produção da empresa na bacia, o Roncador, também para a Equinor. Houve, do mesmo modo, a cessão total de campos terrestres na Bacia Potiguar, bem como a venda ou a colocação à venda da quase totalidade dos campos em terra e no mar na Bacia do Espírito Santo e, também, a venda ou o anúncio de venda dos campos do Recôncavo baiano e diversos outros campos em outras bacias. 


\section{Quadro 01: Ativos de produção e exploração de petróleo e gás vendidos pela Petrobras entre 2016 e 2020}

\begin{tabular}{|c|c|c|c|c|}
\hline \multicolumn{5}{|c|}{ Venda de campos de Produção e exploração de petróleo e gás no Brasil } \\
\hline Transação & Localização & Ano & $\begin{array}{l}\text { Valor } \\
\text { (milhão de } \\
\text { dólares) }\end{array}$ & Comprador \\
\hline $\begin{array}{c}\text { Cessão total da } \\
\text { participação da Petrobras } \\
\text { no Campo de Azulão }\end{array}$ & $\begin{array}{l}\text { Bacia do } \\
\text { Amazonas }\end{array}$ & 2018 & 54,5 & Eneva (Alemanha) \\
\hline Quatro campos terrestres & Bacia do Tucano & 2020 & 3,173 & $\begin{array}{l}\text { Eagle Exploração de } \\
\text { Óleo e Gás Ltda (Eagle) }\end{array}$ \\
\hline $\begin{array}{c}\text { Cessão total em } 34 \\
\text { campos de produção } \\
\text { terrestres, localizados na } \\
\text { Bacia Potiguar, no estado } \\
\text { do Rio Grande do Norte }\end{array}$ & Bacia Potiguar & 2019 & 266 & $\begin{array}{l}\text { Potiguar E\&P S.A, } \\
\text { subsidiária da } \\
\text { Petrorecôncavo S.A }\end{array}$ \\
\hline $\begin{array}{l}\text { Campos terrestres de } \\
\text { Fazenda Belém e Icapuí, } \\
\text { denominado Polo Fazenda } \\
\text { Belém }\end{array}$ & $\begin{array}{l}\text { Bacia Potiguar, no } \\
\text { estado do Ceará }\end{array}$ & 2020 & 35,2 & $\begin{array}{l}\text { SPE Fazenda Belém } \\
\text { S.A., subsidiária } \\
\text { integral da 3R } \\
\text { Petroleum e } \\
\text { Participações S.A. }\end{array}$ \\
\hline $\begin{array}{c}\text { Polo Macau - Sete campos } \\
\text { de produção terrestres, } \\
\text { localizados na Bacia } \\
\text { Potiguar }\end{array}$ & Bacia Potiguar & 2020 & 191,1 & $\begin{array}{l}\text { PE 3R Petroleum S.A., } \\
\text { subsidiária integral da } \\
\text { 3R Petroleum e } \\
\text { Participações S. A }\end{array}$ \\
\hline $\begin{array}{c}\text { Dois campos de produção } \\
\text { terrestres (Ponta do Mel e } \\
\text { Redonda) }\end{array}$ & Bacia Potiguar & 2020 & 7,2 & $\begin{array}{l}\text { Central Resources do } \\
\text { Brasil }\end{array}$ \\
\hline $\begin{array}{l}\text { Campos de Pescada, } \\
\text { Arabaiana e Dentão }\end{array}$ & Bacia Potiguar & 2020 & 1,5 & $\begin{array}{l}\text { OP Pescada Óleo e Gás } \\
\text { Ltda., subsidiária } \\
\text { integral da Ouro Preto } \\
\text { Óleo e Gás S.A., }\end{array}$ \\
\hline $\begin{array}{c}\text { Campo terrestre de Rabo } \\
\text { Branco (Carmopólis-SE) }\end{array}$ & $\begin{array}{l}\text { Bacia Sergipe- } \\
\text { Alagoas }\end{array}$ & 2020 & 1,5 & $\begin{array}{c}\text { Energizzi Energia do } \\
\text { Brasil }\end{array}$ \\
\hline $\begin{array}{c}12 \text { campos terrestres de } \\
\text { exploração e produção, } \\
\text { denominados Polo } \\
\text { Remanso }\end{array}$ & Recôncavo & 2020 & 30 & Petrorecôncavo S.A. \\
\hline $\begin{array}{l}\text { Quatorze campos } \\
\text { terrestres de exploração e } \\
\text { produção, denominados } \\
\text { Polo Recôncavo }\end{array}$ & Recôncavo & 2020 & 250 & $\begin{array}{c}\text { Ouro Preto Energia } \\
\text { Onshore S.A subsidiária } \\
\text { integral da 3R } \\
\text { Petroleum e } \\
\text { Participações S.A } \\
\end{array}$ \\
\hline $\begin{array}{l}\text { Campos de produção de } \\
\text { Peroá e Cangoá e BM-ES- }\end{array}$ & $\begin{array}{l}\text { Bacia Espírito } \\
\text { Santo }\end{array}$ & 2021 & 55 & $\begin{array}{c}\text { OP Energia (3R } \\
\text { Petroleum) e DBO } \\
\text { Energia }\end{array}$ \\
\hline
\end{tabular}




\begin{tabular}{|c|c|c|c|c|}
\hline $\begin{array}{l}\text { 21, denominados } \\
\text { conjuntamente Polo Peroá }\end{array}$ & & & & \\
\hline Polo Cricaré & $\begin{array}{l}\text { Bacia Espírito } \\
\text { Santo }\end{array}$ & 2020 & 155 & $\begin{array}{l}\text { Karavan SPE Cricaré S.A } \\
\text { (Karavan O\&G } \\
\text { Participações e } \\
\text { Consultoria Ltda. } \\
\text { deterá } 51 \% \text { da SPE, } \\
\text { enquanto a empresa } \\
\text { Seacrest Capital Group } \\
\text { Limited, que figura } \\
\text { como equity provider, } \\
\text { deterá os demais } 49 \% \text { ) }\end{array}$ \\
\hline Polo de Lagoa Parda & $\begin{array}{l}\text { Bacia Espírito } \\
\text { Santo }\end{array}$ & 2019 & 9,4 & $\begin{array}{l}\text { Imetame (Espírito } \\
\text { Santo, Brasil) }\end{array}$ \\
\hline $\begin{array}{l}\text { Venda dos campos de } \\
\text { Enchova e Pampo }\end{array}$ & Bacia de Campos & 2019 & 365,4 & $\begin{array}{c}\text { Trident Energy (Reino } \\
\text { Unido) }\end{array}$ \\
\hline $\begin{array}{c}\text { Cessão total da } \\
\text { participação da Petrobras } \\
\text { no Campo Maromba }\end{array}$ & Bacia de Campos & 2019 & 90 & $\begin{array}{c}\text { BW Offshore } \\
\text { Production do Brasil } \\
\text { Ltda (Cingapura e } \\
\text { Noruega) }\end{array}$ \\
\hline $\begin{array}{l}\text { Cessão da participação } \\
\text { total nos campos de } \\
\text { Pargo, Carapeba e } \\
\text { Vermelho, o chamado } \\
\text { Polo Nordeste, localizados } \\
\text { em águas rasas na costa } \\
\text { do estado do Rio de } \\
\text { Janeiro }\end{array}$ & Bacia de Campos & 2019 & 370 & $\begin{array}{l}\text { Perenco Petróleo e Gás } \\
\text { (franco-britânica) }\end{array}$ \\
\hline $\begin{array}{l}\text { Cessão de } 50 \% \text { dos } \\
\text { direitos de exploração e } \\
\text { produção do campo de } \\
\text { Tartaruga Verde e Módulo } \\
\text { III do campo de Espardate }\end{array}$ & Bacia de Campos & 2019 & 692 & Petronas (Malásia) \\
\hline $\begin{array}{c}\text { Venda } 25 \% \text { de } \\
\text { participação no campo de } \\
\text { Roncador para Equinor }\end{array}$ & Bacia de Campos & 2018 & 2.900 & Equinor (Noruega) \\
\hline $\begin{array}{c}\text { Cessão total da } \\
\text { participação da Petrobras } \\
\text { nos campos de Pargo, } \\
\text { Carapeba e Vermelho, } \\
\text { polo nordeste da Bacia de } \\
\text { Campos }\end{array}$ & Bacia de Campos & 2018 & 823 & $\begin{array}{l}\text { Perenco (franco- } \\
\text { britânica) }\end{array}$ \\
\hline $\begin{array}{l}\text { Venda de } 22,5 \% \text { dos } \\
\text { direitos na área de } \\
\text { concessão de lara, e a } \\
\text { cessão de direitos de } 35 \% \text {, } \\
\text { bem como a operação, na } \\
\text { área de concessão do }\end{array}$ & Bacia de Santos & 2018 & 2.200 & Total (França) \\
\hline
\end{tabular}




\begin{tabular}{|c|c|c|c|c|}
\hline $\begin{array}{c}\text { campo de Lapa, no Bloco } \\
\text { BM-S-9 para a Total }\end{array}$ & & & & \\
\hline $\begin{array}{l}\text { Cessão de direitos de } 10 \% \\
\text { do campo de Lapa para a } \\
\text { Total, no Bloco BM-S-9. } \\
\text { Exercício da opção de } \\
\text { venda do restante da } \\
\text { participação, conforme } \\
\text { previsto no contrato } \\
\text { assinado em janeiro de } \\
\text { 2018, quando a Total } \\
\text { adquiriu 35\% da } \\
\text { participação da Petrobras, } \\
\text { ficando com a operação } \\
\text { do campo }\end{array}$ & Bacia de Santos & 2018 & 50 & Total \\
\hline $\begin{array}{c}\text { Aliança estratégica com } \\
\text { Total, incluindo a cessão } \\
\text { de } 22,5 \% \text { dos direitos na } \\
\text { área de concessão de } \\
\text { lara, e a cessão de } \\
\text { direitos de } 35 \% \text {, bem } \\
\text { como a operação, na } \\
\text { área de concessão do } \\
\text { campo de Lapa, no Bloco } \\
\text { BM-S-9 }\end{array}$ & Bacia de Santos & 2018 & 2.200 & Total \\
\hline $\begin{array}{l}\text { Venda da Participação de } \\
76 \% \text { no Bloco exploratório } \\
\text { BM-S-8 (Carcará) para a } \\
\text { Equinor. Hoje controlado a } \\
\text { 100\% pela Equinor }\end{array}$ & Bacia de Santos & 2016 & 2.500 & Equinor (Noruega) \\
\hline TOTAL & & & $12.849,4$ & \\
\hline
\end{tabular}

Fonte: Notícias nos sites dos jornais Valor, G1, Folha de São Paulo, Revista Exame, Fatos e Dados, Agencia Petrobras, Epbr e Relatórios anuais da Petrobras (2017-2019).

Essas vendas farão com que a Petrobras fique ausente totalmente de determinadas bacias: Pelotas, Pará-Maranhão, Ceará, Potiguar, Tucano do Sul, Recôncavo na Bahia (onde se localiza o primeiro poço comercial explorado no país em 1941) e do Espírito Santo. 
No que segue descreveremos brevemente uma tipologia do modo de privatização de campos no Espírito Santo, o que, acreditamos, poderia ser projetado para outros lugares em função dos interesses em jogo. Em seguida a essa exposição apresentaremos as privatizações de setores inteiros da empresa no exterior e depois das atividades conexas ao setor de exploração e produção.

Breve descrição das transações relativas aos campos de petróleo e gás no Espírito Santo

Para melhor compreender o processo de privatização vejamos o modus operandi das vendas dos campos, de dimensões modestas comparadas a outros grandes campos da Bacia de Campos e Santos, que já ocorreram no Espírito Santo e os interesses em jogo que envolvem ex-dirigentes da Petrobras e de órgãos públicos do setor do petróleo que também tiveram um papel importante nos processos de privatização da empresa. Descreveremos abaixo a venda de um conjunto de campos no norte do estado.

O polo Lagoa Parda localizado próximo a foz do Rio Doce no Sul do município de Linhares-ES teve sua venda concluída em outubro de 2020. A denominação de polo vem do fato das sinergias operacionais formadas pela infraestrutura - rede de dutos, bombas de vareta de sucção (bombas cavalo-de-pau) uma Unidade de Processamento de Gás Natural (UPGN), com capacidade de processar 1,25 milhão de metros cúbicos diários, uma Estação de Tratamento de Líquidos com capacidade de 25 mil barris diários, rede viária, etc. - construídas pela Petrobras e envolvendo 3 campos produtores (Lagoa Parda, Lagoa Parda Norte e Lagoa Piabanha). Juntos, em 2017, esses campos produziram, respectivamente, 270,47 barris de petróleo e 19,92 $\mathrm{m}^{3}$ de gás por dia. Inicialmente, a empresa capixaba Imetame realizou a compra do ativo pagando o valor de 9,4 milhões de dólares (49 milhões de reais de acordo com a cotação de outubro de 2020). Cerca de $81 \%$ desse valor (40 milhões de reais) foi financiado junto a um consórcio firmado entre dois bancos públicos estaduais do Espírito Santo: BANESTES (Banco do Estado do Espírito Santo) e BANDES (Banco de Desenvolvimento do Espírito 
Santo). Cada banco entrou no negócio com 40,5\% (20 milhões de reais) do valor e a Imetame com apenas 19\% (9 milhões de reais).

Assim, mantendo-se as condições de produção atuais, em menos de 4 anos a produção irá pagar o valor da aquisição, sem levar em conta os juros dos empréstimos efetuados junto aos bancos, conforme aponta o quadro 02 , demonstrando que o negócio foi muito interessante e nos interrogando sobre os modos de avaliação dos valores de ativos colocados à venda pela empresa. Ademais, esses campos maduros que são explorados há muitos anos necessitam de novo investimento e, dependendo do tipo de empresa que os controlarão e dos interesses que envolvem essas vendas, esse investimento poderá não se realizar. A gestão fragmentária da exploração e produção, antes assegurada por uma só empresa, multiplicará o número de atores com os quais as autoridades reguladoras estatais e, notadamente ambientais, deverão lhe dar, multiplicando a possibilidade de se ter mais acidentes e maiores riscos de vazamentos diversos, pelo fato de pequenas empresas terem menos condições financeiras que uma grande empresa como a Petrobras. O que, claro não deve minimizar as dezenas de incidentes cotidianos que ocorrem nesses campos sob a gestão da Petrobras, como já verificamos em trabalhos de campo em 2019.

Quadro 02: Valores da negociação do polo Lagoa Parda e possível ressarcimento do empréstimo para a sua aquisição pela Imetame.

\begin{tabular}{|c|c|c|c|c|c|c|c|}
\hline $\begin{array}{c}\text { I } \\
\text { Produção } \\
\text { média } \\
\text { diária }\end{array}$ & $\begin{array}{c}\| \\
\text { Preço médio } \\
\text { do Barril de } \\
\text { petróleo em } \\
2020 \mathrm{em} \\
\text { reais }\end{array}$ & $\begin{array}{c}\text { III } \\
\text { Custo médio } \\
\text { da produção } \\
\text { do barril de } \\
\text { Petróleo em } \\
\text { terra } * * *\end{array}$ & $\begin{array}{l}\text { IV } \\
(|\mathrm{x}| \mathrm{I}) \\
\text { Receita } \\
\text { média } \\
\text { diária }\end{array}$ & $\begin{array}{l}\mathrm{V} \\
(\mathrm{I} \times \mathrm{III}) \\
\text { Custo } \\
\text { médio } \\
\text { diário }\end{array}$ & $\begin{array}{l}\text { VI } \\
\text { IV - V } \\
\text { Lucro } \\
\text { médio } \\
\text { diário }\end{array}$ & $\begin{array}{c}\text { VII } \\
\text { (49 milhões/VI) } \\
\text { Tempo (em dias) } \\
\text { necessário para } \\
\text { atingir os } 49 \\
\text { milhões do valor } \\
\text { do ativo (em } \\
\text { meses) }\end{array}$ & $\begin{array}{c}\text { Tempo em } \\
\text { anos } \\
\text { necessário } \\
\text { para atingir } \\
\text { os } 49 \text { milhões } \\
\text { (em anos) } \\
\text { (VII/365) }\end{array}$ \\
\hline $270 *$ & $235,2 * *$ & 100,8 & 63504 & 27216 & 36288 & 1350,3 & 3,7 \\
\hline
\end{tabular}

Fonte: Petrobras, 2018, IndexMundi (2020) e Jornal Estadão (2019).

*Teaser Petrobras Lagoa Parda (2018).

** IndexMundi (2020) - Média considerando o preço (Brent) médio do barril entre janeiro e novembro de 2020.

*** Jornal Estadão (2019). 
Analisando os dados referentes aos concessionários e operadores de campos e blocos, nota-se um intenso movimento de aquisições, fusões, criação de subsidiárias e outras engenharias societárias. No caso da Imetame, no polo de Lagoa Parda a empresa vendeu 50\% de suas participações para a empresa Petro-Victory Energy, com sede no Texas e escritório administrativo no Rio de Janeiro, por 4,68 milhões de dólares. Por sua vez, a empresa Petro-Victory Energy vendeu sua participação para a empresa EnP Energy Platform, uma empresa pertencente ao ex-secretário de Petróleo e Gás do Ministério de Minas e Energia, Márcio Felix Carvalho Bezerra. Ela tem ainda como diretores Fernando Taboada, geólogo e ex-gerente de Exploração da Petrobras no Espírito Santo, Cristiane Formosinho, que trabalhou durante 37 anos na Petrobras, o engenheiro aposentado Marco Túlio Pereira Machado, ex-gerente executivo da Petrobras e, por fim, a engenheira Lucia de Fátima, que trabalhou 39 anos em atividades de exploração e produção onshore e offshore na Petrobras $(E n P, 2021)^{13}$. Os valores referentes à compra feita pela EnP não foram divulgados publicamente.

Márcio Felix, como é chamado o dono da empresa EnP Energy Platform, trabalhou na Petrobras por 33 anos, onde atuou como gerente-geral de Exploração e Produção na América do Norte e na África e fez parte da gerência geral de Exploração e Produção da empresa no Espírito Santo. Foi no passado Secretário de Estado no Espírito Santo. Em 2016 assumiu o cargo de Secretário de Petróleo, Gás Natural e Combustíveis Renováveis do Ministério de Minas e Energia, onde ficou até setembro de $2019^{14}$, e nesse período colaborou na implantação da agenda de privatização da Petrobras. Entre 2018 e março de 2020 foi presidente do conselho de administração da empresa pública Pré-Sal Petróleo (PPSA), ${ }^{15}$ que organiza notadamente os leilões de venda do petróleo recebido pela União em pagamento dos contratos de partilha na área do pré-sal.

\footnotetext{
${ }^{13}$ Diretoria da empresa Enp disponível em: https://enpbr.com/diretoria/.

14 Petronotícias, 17/06/2016. Disponível em https://petronoticias.com.br/confirmado-o-nome-demarcio-felix-para-secretaria-de-petroleo-e-gas-do-mme/, consultado em 05/02/2021).

15 Cf. Atas do Conselho de Administração da Pré-sal Petróleo, disponíveis em http://presalpetroleo.gov.br/ppsa/governanca-corporativa/conselho-de-administracao. Acesso em fev. 2021).
} 
Em março de 2020 assumiu a vice-presidência executiva da Organização Nacional da Indústria do Petróleo - ONIP que é um órgão ligado às federações empresariais industriais (FIRJAN, FIESP, etc.) e que tem como visão "ser protagonista na articulação entre as companhias operadoras, as indústrias de bens e serviços, as agências de fomento e o governo, contribuindo para o aumento da competitividade global do mercado de óleo e gás brasileiro."16 É ainda presidente para o período de julho de 2019 a julho de 2021 do conselho de administração de empresa constituída recentemente, ES Gás, distribuidora de gás natural do Espírito Santo, por meio da Lei Ordinária $\mathrm{N}^{\circ}$ 10.955/2018. A ES GÁS é uma empresa de economia

"O quadro atual do grupo Petrobras é muito movente. A venda de empresas nos mais diversos setores do grupo, de campos e de ações é tão recorrente que se torna extremamente difícil acompanhar o processo de privatização". mista em que o Estado do Espírito Santo detém 51\% do capital votante, tendo como sócia a BR Distribuidora, com os demais $49 \%$. Essa empresa, apenas constituída, teve sua privatização anunciada recentemente pelo governo do estado para o ano de 2022 e haveria o interesse de transnacionais em sua compra. No Espírito Santo, ela é a concessionária responsável pela distribuição do gás natural canalizado, regulada pelo órgão estadual ARSP

(Agência de Regulação de Serviços Públicos do Espírito Santo). A empresa atua nos segmentos residencial, comercial, industrial, automotivo, de climatização, cogeração e termoelétrico, totalizando mais de 60 mil unidades consumidoras. ${ }^{17}$

Assim, Márcio Félix parece ser um personagem que ocupa múltiplas funções nos no setor de petróleo e gás; aparentemente tem como única crença o "mercado" incensado pelos patrões do momento; passa da administração pública para o setor privado sem nenhuma cerimônia, utilizando as famosas "portas giratórias" onde se usa das informações e relações adquiridas na administração pública e prepara as privatizações

\footnotetext{
16 Disponível em https://www.onip.org.br/institucional/nosso-proposito. Acesso em nov. 2020.

17 Sobre as funções de Marcio Felix consulte-se o site https://epbr.com.br/marcio-felix-e-o-novo-vicepresidente-executivo-da-onip/. Acesso em nov. 2020. Sobre as funções e a constituição da empresa Présal petróleo consultar o site https://www.presalpetroleo.gov.br/ppsa/portal/default.php, Acesso em nov. 2020. E sobre a Es Gás pode-se consultar https://esgas.com.br/governanca-corporativa/ , Acesso em nov. 2020. Sobre a privatização conforme A Gazeta on line, 4/05/2021, disponível em agazeta.com.br.
} 
de empresas controladas pelo Estado, para se cacifar para exercer cargos em organizações patronais e do setor privado, transformando-se, finalmente, em empresário do setor.

Nota-se, assim, não haver nenhuma distinção entre público e privado nesses processos: Márcio Felix foi presidente do conselho de administração de uma empresa pública que decide sobre os contratos de gestão do regime de partilha do pré-sal e é presidente do conselho de administração de uma empresa de economia mista que decide sobre a distribuição de gás no Espírito Santo que já tem sua privatização anunciada. Ao mesmo tempo, é membro de uma organização patronal que tem interesses empresariais no objeto dessas empresas e, por fim, depois de participar das políticas ligadas ao petróleo e gás nessas instâncias e participar dos processos de incentivo à venda de ativos da Petrobras e dos leilões de blocos de petróleo, adquire participação em campos de produção de petróleo da empresa em que trabalhou e sobre a qual tinha um poder de influência como secretário do setor no Ministério das Minas e Energia.

Vemos aqui, no exemplo dado, como o governo do Estado é exercido como uma extensão da empresa, o governo é internamente regulado como uma empresa e os agentes que exercem os poderes no interior do Estado estão imbuídos de um habitus que os leva a ver como totalmente normal, como normalizado, utilizar o Estado e as empresas que controla para seus próprios interesses.

Como demonstra Foucault (2004b: 171-177) em Nascimento da Biopolítica, quando analisa o pensamento e as ações neoliberais, as transformações institucionais do próprio Estado e as "regulações" legitimadas por leis que solidificam as normas no interior do Estado no neoliberalismo seguem a máxima de um "intervencionismo jurídico" que fazem com que as leis de mercado e o princípio de regulação econômica geral, baseados na empresa e na competição, sejam adotados pelos governos como princípio de visão do mundo. Como indica Foucault sobre os neoliberais alemães no passado, os ordoliberais, que tiveram uma influência na disseminação desses preceitos a nível mundial, dizem que o Estado tem defeitos intrínsecos e, portanto, teria que se ir mais longe que os liberais do século XIX e início do século XX que defendiam o princípio de "limitação do Estado" na economia de mercado, quando o Estado deveria intervir o 
mínimo no mercado deixando-o livre para a sua suposta realização natural, e para isso exercendo o papel de "regulador" externo do mesmo. Os neoliberais vão mais longe e defendem que o mercado deveria ser o princípio de regulação interna do Estado, o que é resumido em uma fórmula: "um Estado sob vigilância do mercado antes que um mercado sob vigilância do Estado" (FOUCAULT, 2004b).

Poderíamos pensar que o Estado brasileiro está internamente sob a vigilância do mercado, tanto por meio dos tribunais que definem o quadro neoliberal da concorrência, mas também quando os agentes do Estado vigiam por dentro o Estado e são agentes do próprio mercado agindo com a legitimidade do mercado e compreendendo o Estado como uma extensão do mercado, o que os faz confundir seus interesses próprios de agentes do mercado com os interesses do Estado. Distorcendo assim o quadro legal que os neoliberais pretendiam como imparcial para impedir monopólios e utilização privilegiada da posição de regulador. Mas nunca se abandona a legitimidade construída com a ideia de soberania associada como vimos ao Estado.

Em suma, o caso analisado da privatização do polo de Lagoa Parda e do papel jogado por Márcio Felix é emblemático, ele revela um neoliberalismo que se pauta pelas normas à geometria variável produzidas em função do interesse de um determinado grupo de agentes e não do interesse de todos os indivíduos em conjunto em uma dada sociedade, vistos como unidades empresariais de si mesmos, como pretendem os neoliberais num mercado aberto. As normas do jogo são mudadas durante o jogo, os agentes públicos ou de empresas estatais não jogam o jogo da competição clara num quadro claro de regras claras, como pretendem reiteradamente os neoliberais, mas sim têm informações privilegiadas que eles fazem frutificar, uma vez no mercado, como indivíduos-empresas e se legitimando pelo papel simbólico e material do Estado no exercício do poder reconhecido como acima de todos.

Essa lógica neoliberal será agora vista na privatização dos ativos da Petrobras no exterior que obedece a outras estratégias. 


\subsection{A privatização dos ativos da Petrobras no exterior}

As privatizações não se limitam ao território nacional e ao segmento upstream. A Petrobras vem se desfazendo de muitas participações internacionais em todos os segmentos conforme aponta o quadro 03, sobretudo a partir de 2016, arrecadando um valor total de 7,59 bilhões de dólares por meio das vendas realizadas.

Quadro 03: Vendas das Participações internacionais da Petrobras de 2013 a 2020

\begin{tabular}{|c|c|c|c|c|c|}
\hline \multicolumn{6}{|c|}{ Vendas das Participações internacionais } \\
\hline Transação & Localização & Segmento & Ano & $\begin{array}{c}\text { Valor } \\
\text { (bilhões } \\
\text { de } \\
\text { dólares) }\end{array}$ & Comprador \\
\hline $\begin{array}{c}\text { Petrobras Colômbia } \\
\text { Combustibles }\end{array}$ & Colômbia & Distribuição & 2020 & ND & Perenco \\
\hline $\begin{array}{c}\text { Alienação integral da } \\
\text { participação societária da } \\
\text { Petrobras nas empresas } \\
\text { Petrobras Paraguay } \\
\text { Distribución Limited (PPDL } \\
\text { UK), Petrobras Paraguay } \\
\text { Operaciones y Logística SRL } \\
\text { (PPOL) e Petrobras Paraguay } \\
\text { Gas SRL (PPG) }\end{array}$ & Paraguai & Distribuição & 2019 & 0,38 & $\begin{array}{l}\text { Paraguay } \\
\text { Energy - } \\
\text { Grupo } \\
\text { Copetrol } \\
\text { (Peru) }\end{array}$ \\
\hline $\begin{array}{l}\text { Alienação integral da } \\
\text { participação societária detida } \\
\text { pela Petrobras (50\%) na } \\
\text { empresa Petrobras Oil \& Gas } \\
\text { B.V. ("PO\&G BV") }\end{array}$ & $\begin{array}{l}\text { Participações } \\
\text { da Petrobras } \\
\text { na África com } \\
\text { o BTG Pactual }\end{array}$ & Exploração & 2019 & 1,53 & \begin{tabular}{|} 
Petrovida, \\
Vitol \\
Investments \\
Partnership, \\
Africa Oil \\
Corp \\
(Canadá) e \\
Delonex \\
Energy \\
(Reino \\
Unido).
\end{tabular} \\
\hline $\begin{array}{l}\text { Constituição de joint venture } \\
\text { composta por ativos em } \\
\text { produção de petróleo e gás } \\
\text { natural no Golfo do México }\end{array}$ & $\begin{array}{l}\text { Golfo do } \\
\text { México }\end{array}$ & Exploração & 2018 & 1,1 & $\begin{array}{c}\text { Murphy } \\
\text { Exploration } \\
\text { \& } \\
\text { Production }\end{array}$ \\
\hline
\end{tabular}




\begin{tabular}{|c|c|c|c|c|c|}
\hline $\begin{array}{l}\text { entre a subsidiária Petrobras } \\
\text { America Inc. ( } 20 \% \text { ) e a } \\
\text { empresa Murphy Exploration } \\
\text { \& Production Company que } \\
\text { compra e passa a ser } \\
\text { responsável pelas atividades } \\
\text { de operação }(80 \%)\end{array}$ & & & & & $\begin{array}{l}\text { Company } \\
\text { (EUA) }\end{array}$ \\
\hline $\begin{array}{l}\text { Alienação integral das ações } \\
\text { detidas pela Petrobras } \\
\text { America Inc. nas empresas } \\
\text { que compõem o sistema de } \\
\text { refino de Pasadena, nos } \\
\text { Estados Unidos }\end{array}$ & $\begin{array}{l}\text { Estados } \\
\text { Unidos }\end{array}$ & Refino & 2018 & 0,56 & Chevron \\
\hline $\begin{array}{c}\text { Venda da Pesa (Petrobras } \\
\text { Argentina) }\end{array}$ & Argentina & Distribuição & 2016 & 0,892 & $\begin{array}{c}\text { Pampa } \\
\text { Energia } \\
\text { (Argentina) }\end{array}$ \\
\hline $\begin{array}{l}\text { Venda da refinaria Nansei } \\
\text { Sekiyu no Japão }\end{array}$ & Japão & Refino & 2016 & 0,165 & $\begin{array}{c}\text { Taiyo Oil } \\
\text { Company } \\
\text { (Japão) }\end{array}$ \\
\hline $\begin{array}{l}\text { Venda da Petrobras Chile } \\
\text { Distribuición (PCD) }\end{array}$ & Chile & Distribuição & 2016 & 0,464 & $\begin{array}{l}\text { Souther } \\
\text { Cross Group } \\
\text { (Fundo de } \\
\text { investiment } \\
\text { os) } \\
\end{array}$ \\
\hline Venda dos ativos no Peru & Peru & $\begin{array}{l}\text { Exploração } \\
\text { e produção }\end{array}$ & 2013 & 2,6 & $\begin{array}{l}\text { China } \\
\text { National } \\
\text { Petroleum } \\
\text { Corporation } \\
\text { - CNPC } \\
\end{array}$ \\
\hline TOTAL & & & & 7,691 & \\
\hline
\end{tabular}

Fonte: Notícias nos sites dos jornais Valor, G1, Folha de São Paulo, Revista Exame, Fatos e Dados, Agencia Petrobras, Epbr e Relatórios anuais da Petrobras (2017 - 2019).

Além dos valores, alguns aspectos nessas transações nos chamaram atenção. Em primeiro lugar, constata-se a saída total do segmento de distribuição da empresa na América do Sul e, em segundo lugar, o desengajamento total do continente africano. Aliás, a participação da Petrobras na África foi atípica desde o início em função da associação entre a petroleira com o banco de investimentos BTG Pactual. Esse banco esteve envolvido em uma série de processos no interior da operação Java jato, com a prisão de seu presidente em 2015, André Esteves - que é ainda hoje o principal acionista do banco e que voltou a geri-lo sem provocar aparentemente nenhuma vaga de 
contestação por parte dos tenores da moral anticorrupção. O BTG Pactual é um banco de investimentos que tem como um dos seus sócios fundadores o atual ministro da economia Paulo Guedes. Este ministro teria favorecido aparentemente o Banco Pactual18 em recente licitação para "gerir" os dados pessoais dos funcionários públicos federais (Cf. Carta Capital, 14/01/2020) e outras transações em setores diversos. Por outro lado, conforme notícia o jornal O Petróleo (18/02/2020):

No ano passado [2019], a polícia federal do Brasil invadiu a sede do banco em São Paulo duas vezes. Em agosto, eles realizaram pesquisas relacionadas à compra de participações em 2013 em alguns campos de petróleo africanos da produtora estatal de petróleo, a Petróleo Brasileiro SA.

Quando se privatiza, como estamos vendo, o grupo Petrobras, os fundos de investimentos, os bancos e os setores interessados neste processo são aqueles com os quais o próprio ministro trabalha. Parece-nos que aqui se está reproduzindo a forma de privatizações que ocorreram nos anos 1990 com os governos Fernando Henrique Cardoso (ZANOTELLI, 1998).

\subsection{Privatização das subsidiárias, das coligadas, das controladas, das refinarias e da distribuição de combustível da Petrobras}

A Petrobras contava em 2018 com mais de 600 mil acionistas, estava até recentemente presente em 19 países e possuía um quadro de 63.361 trabalhadores diretos no grupo Petrobras, incluindo as coligadas e controladas.

Com cerca de 120 plataformas de produção no mar, a estatal possuía até o início de 2020 diretamente 13 refinarias no Brasil e três no exterior, duas dessas últimas já foram

\footnotetext{
${ }^{18}$ Segundo nos revela Ladislau Dowbor, o BTG Pactual é um banco de gestão de fortunas que detêm 38 filiais em paraísos fiscais, o economista se interroga do porquê tentas agências nesses territórios onde paga-se pouco impostos e onde se faz vista grossa sobre a origem do dinheiro (evasão fiscal, dinheiro de corrupção, etc.). Ver DOWBOR, Ladislau. Palestra Fluxo financeiro integrado. Disponível em https://youtu.be/eh8AGdBPuwc. Acesso em fev. 2021.
} 
vendidas como vimos, com uma produção de derivados de 1 milhão e 800 mil barris por dia. Ela tinha em 2018 uma frota composta por 55 navios, a empresa e suas coligadas contavam, também, com $7.710 \mathrm{~km}$ de oleodutos e $9.190 \mathrm{~km}$ de gasodutos, cinco unidades de produção de bicombustíveis, 20 usinas termelétricas. Tinha em 2018 a participação em quatro usinas de energia eólica e possui uma usina de energia solar, além de três fábricas de fertilizantes e 8.277 postos de gasolinas, sendo 388 localizados no exterior. ${ }^{19}$

O quadro atual do grupo Petrobras é muito movente. A venda de empresas nos mais diversos setores do grupo, de campos e de ações é tão recorrente que se torna extremamente difícil acompanhar o processo de privatização por que passa, mais abaixo listaremos o conjunto das recentes privatizações de subsidiárias e controladas pela empresa, bem como de setores do próprio grupo Petrobras que são ligados diretamente à empresa mãe e, portanto, não poderiam ser vendidos.

\subsubsection{A privatização de plantas industriais e das infraestruturas da Petrobras a partir} de 2016

O que demonstra uma dissolução gradual do grupo Petrobras é a privatização de áreas estratégias para qualquer empresa de energia verticalizada. Destaca-se nesse sentido a venda de extensas redes de gasodutos, anúncio de venda e venda de refinarias, termelétricas, empresas de biodiesel, petroquímicas, fábricas de fertilizantes, fábricas de asfalto, dentre outras. Muitas dessas vendas, como veremos, não estão conforme a legislação. 0 mapa 03 e o quadro 04 indicam esses ativos vendidos e colocados à venda.

\footnotetext{
${ }^{19}$ Disponível em http://www.petrobras.com.br/pt/quem-somos/perfil/. Acesso em out. 2018.
} 
Mapa 03: Plantas industriais e infraestruturas vendidas e com anúncio de venda pela Petrobras entre 2017 e janeiro de 2021

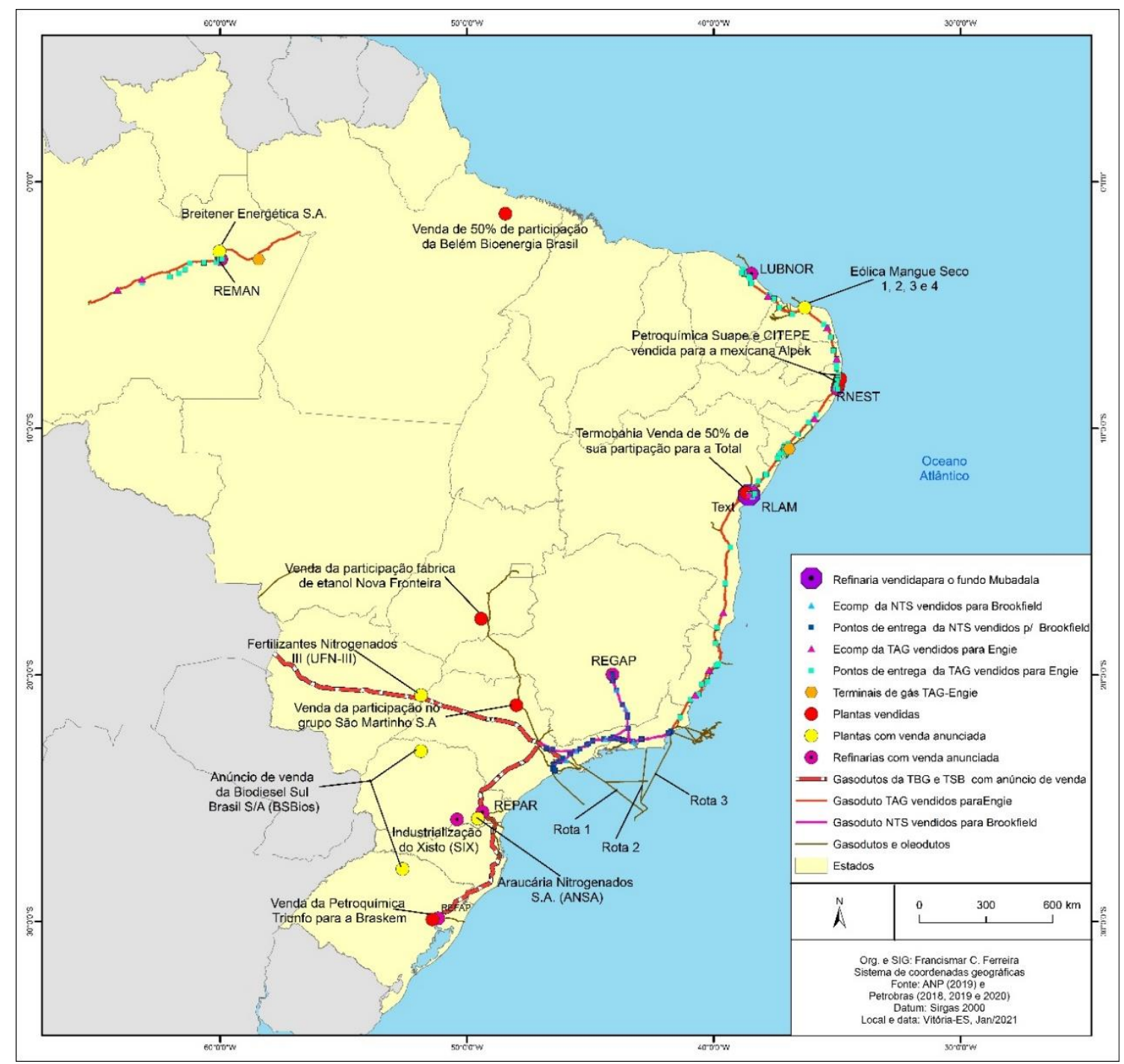




\section{Quadro 04: Privatizações de 2016 a 2020 de Infraestruturas e plantas industriais controlados pela Petrobras}

\begin{tabular}{|c|c|c|c|c|}
\hline \multicolumn{5}{|c|}{ Vendas de Infraestruturas e plantas industriais } \\
\hline Transação & Localização & Ano & $\begin{array}{c}\text { Valor } \\
\text { (bilhões de } \\
\text { dólares) }\end{array}$ & Comprador \\
\hline $\begin{array}{l}\text { Refinaria Landulpho Alves } \\
\text { (RLAM) }\end{array}$ & Bahia & 2020 & 1,65 & $\begin{array}{c}\text { Grupo Mubadala } \\
\text { dos Emirados } \\
\text { Árabes Unidos }\end{array}$ \\
\hline $\begin{array}{c}\text { Venda dos } 10 \% \text { restante da } \\
\text { Transportadora Associada de } \\
\text { Gás (TAG) }\end{array}$ & Brasil & 2020 & ND & $\begin{array}{l}\text { Caisse de dépôt et } \\
\text { placement du } \\
\text { Québec (“CDPQ") }\end{array}$ \\
\hline $\begin{array}{l}\text { Venda de } 49 \% \text { na produtora } \\
\text { de etanol Nova Fronteira }\end{array}$ & Goiás & 2016 & 0,133 & $\begin{array}{c}\text { Grupo São } \\
\text { Martinho (Brasil) }\end{array}$ \\
\hline $\begin{array}{l}\text { Venda de } 90 \% \text { da unidade de } \\
\text { gasodutos Nova } \\
\text { Transportadora Sudeste (NTS) }\end{array}$ & Brasil & $2016 / 2017$ & 5,19 & $\begin{array}{c}\text { Brookfield } \\
\text { (Canadá) } \\
\text { ITAU quanto tem? }\end{array}$ \\
\hline $\begin{array}{c}\text { Venda de } 50 \% \text { da Termobahia } \\
\text { S.A, para a Total }\end{array}$ & Bahia & 2017 & 2,2 & Total \\
\hline $\begin{array}{c}\text { Venda do Total de ações da } \\
\text { São Martinho S.A - setor } \\
\text { sucro-alcoleiro e de energia } \\
(6,593 \%)\end{array}$ & MG e SP & 2018 & 0,14 & $\begin{array}{l}\text { Acionistas em } \\
\text { Bolsa de Valores }\end{array}$ \\
\hline $\begin{array}{l}\text { Alienação da Companhia } \\
\text { Petroquímica de Pernambuco } \\
\text { (Petroquímica Suape) e } \\
\text { Companhia Integrada Têxtil } \\
\text { de Pernambuco (Citepe) }\end{array}$ & $\begin{array}{c}\text { Pernambuc } \\
\text { o }\end{array}$ & 2018 & 0,44 & Alpek (México) \\
\hline $\begin{array}{l}\text { Venda de sua participação } \\
(50 \%) \text { na Belém Bioenergia }\end{array}$ & Belém & 2019 & 0,247 & $\begin{array}{l}\text { Galp Bioenergy } \\
\text { B.V. (Galp) (Brasil) }\end{array}$ \\
\hline $\begin{array}{c}\text { Alienação de } 90 \% \text { de } \\
\text { participação na } \\
\text { Transportadora Associada de } \\
\text { Gás S.A. (TAG) }\end{array}$ & $\begin{array}{l}\text { Brasil } \\
\text { (Sudeste, } \\
\text { Nordeste e } \\
\text { Norte) }\end{array}$ & 2019 & 8,72 & $\begin{array}{l}\text { Engie (França) e } \\
\text { Caisse de dépôt et } \\
\text { placement du } \\
\text { Québec (“CDPQ”) } \\
\text { (Canadá) }\end{array}$ \\
\hline Total & & & 18,72 & \\
\hline
\end{tabular}

Fonte: Notícias nos sites dos jornais Valor, G1, Folha de São Paulo, Revista Exame, Fatos e Dados, Agencia Petrobras, Epbr e Relatórios anuais da Petrobras (2017 - 2019) e Balanço Petrobras (2019). 
Inicialmente, o Quadro 04 chama atenção para a venda do segmento de bicombustíveis. Assim, já foi vendida a fábrica de etanol Novo Fronteira e os $50 \%$ da participação da estatal na Belém Bioenergia. Em ambas as vendas o que chamou a atenção é que foram exatamente os sócios da Petrobras nas plantas que são os compradores. Ou seja, no momento dos investimentos nos projetos o capital da Petrobras os viabilizou; após a consolidação dos investimentos, a Petrobras sai do negócio deixando-o para seus "sócios". É importante destacar ainda que todo o segmento de bicombustíveis que ainda não foi vendido, foi colocado à venda, indicando, assim, um abandono de uma política de transição energética.

Dentre as privatizações das plantas industriais e das infraestruturas, são extremamente relevantes a venda e o anúncio de vendas das subsidiárias responsáveis por extensas, importantes e estratégicas malhas de gasodutos. Conforme aponta o mapa 03, os principais dutos de distribuição e movimentação de gás no Brasil ou já foram vendidos ou estão à venda. Duas subsidiárias do setor de transporte de gás já foram desnacionalizadas até o momento, são elas: a venda em 2016/2017 de 90\% da Nova Transportadora Sudeste (NTS) e a venda em 2019 de 90\% de participação na Transportadora Associada de Gás S.A. (TAG).

A NTS teve a venda de $90 \%$ das ações por 5,19 bilhões de dólares para a Nova Infraestrutura Fundo de Investimentos em Participações (FIP), gerido pela Brookfield Brasil Asset Management Investimentos Ltda., entidade afiliada ao fundo canadense Brookfield Asset Management. Na mesma data, o FIP realizou a venda de parte de suas ações na NTS para a Itaúsa - Investimentos Itaú S.A, o que pode indicar intermediação do banco e/ou algum tipo de financiamento. Vale ressaltar que os $10 \%$ remanescentes de participação da Petrobras na NTS já foram colocados à venda.

A NTS possui mais de $2.000 \mathrm{~km}$ de gasodutos com capacidade para distribuir 158,2 milhões $\mathrm{m}^{3}$ de gás por dia, localiza-se na região sudeste, conforme aponta o mapa 03, que é a região onde se encontra as maiores reservas e os maiores volumes de produção de gás bem como o maior consumo do produto (60\% do gás consumido no Brasil encontra-se nessa região). O único cliente da NTS é a própria Petrobras. A venda dos gasodutos representou uma enorme "irracionalidade" para a Petrobras, que agora paga a NTS pela utilização dos 
gasodutos. De acordo com nota publicada pela $\operatorname{AEPET}^{20}$ (2018), a Petrobras divulgou no seu Relatório ao Mercado Financeiro, relativo ao segundo trimestre de 2017, que a empresa tinha um aumento com gastos logísticos, em função do pagamento de tarifas a terceiros pela utilização dos gasodutos, a partir da venda da NTS. Esse aumento foi de aproximadamente 1.010 milhões de reais. Segundo a nota da AEPET, esse valor corresponde a aproximadamente 1/6 (um sexto) do efetivamente recebido, uma vez feito todos os descontos operados, pela venda da NTS que foi gasto com o aluguel dos próprios gasodutos em apenas um trimestre. Nesse sentido, desconsiderando qualquer correção monetária, todo o valor recebido pela venda da NTS terá sido pago em alugueis em apenas 18 meses (AEPET, 2018).

A privatização da TAG ocorreu em 2019 e aqui se replicam as mesmas consequências relativas à NTS. A TAG foi vendida para a francesa Engie e o fundo Caisse de Dépôt et Placement du Québec (CDPQ) por US\$ 8,72 bilhões, cerca de 33 bilhões de reais à época, o equivalente a cinco anos de lucros da empresa se tomássemos 2016 (7 bilhões de lucros) como parâmetro. Essa foi a maior venda de ativos da Petrobras realizada até hoje, a composição acionária da TAG ficou a seguinte: 58,5\% pertencente à Engie e 31,5\% pertencente ao CDPQ e 10\% da Petrobras. Entretanto, em 2020 a Petrobras concluiu a venda de sua participação para o CDPQ pelo valor de um bilhão de reais. A TAG é formada por uma malha de gasodutos com cerca de $4.500 \mathrm{~km}$ de extensão em 10 estados das regiões Sudeste, nordeste e norte (Cf. mapa 03). Assim como ocorreu com a NTS, foi vendido não um projeto a ser desenvolvido, mas uma infraestrutura com instalações prontas e desenvolvidas pela estatal. Da mesma forma como ocorreu com a NTS, a Petrobras se transformou em cliente da privatizada TAG, logo, paga aluguel para usar os gasodutos que ela construiu e vendeu.

Vale ressaltar que atualmente encontra-se, também, a venda pela Petrobras sua participação de 51\% na Transportadora Brasileira Gasoduto Bolívia-Brasil (TBG) e 25\% de participação na Transportadora Sul-brasileira de Gás S.A. (TSB). A composição acionária da

\footnotetext{
${ }^{20}$ Disponível em: https://aepet.org.br/w3/index.php/conteudo-geral/item/2126-nts-tragediaanunciada-e-responsabilidade. Acesso em fev. 2021.
} 
TBG é de 51\% da Petrobras, 39\% da BBPP Holdings (A Total francesa detém 33\% do capital da BBPP), $8 \%$ do fundo Global Energy Partners (EIG) e 12\% da YPFB Transporte. Por sua vez, a TSB é formada pela Petrobras que detém 25\%, mais as empresas Total (25\%), Ipiranga (grupo Ultra, 25\%), e Repsol (25\%). A venda futura dessas participações da Petrobras representará praticamente o fim da atuação da empresa no transporte de gás no Brasil. Restará a ela apenas os gasodutos que ligam as áreas de produção até as refinarias e terminais de gás.

Por fim, destaca-se o movimento de privatização das refinarias. Oito das 13 refinarias da Petrobras foram colocadas à venda (cf. mapa 03). Dessa, a Refinaria Landulpho Alves (RLAM/BA) foi vendida para o fundo de investimentos dos Emirados Árabes, Mubadala por um valor de US\$ 1,65 bilhão. Segundo A Federação Única dos Trabalhadores (FUP), a partir de um estudo realizado pelo Estudos Estratégicos de Petróleo, Gás Natural e Biocombustíveis (INEEP), a refinaria valeria entre 3 e 4 bilhões de dólares. ${ }^{21}$ Esse refinaria tem em particular um papel no fornecimento de cerca de $30 \%$ da produção da Petrobrás de óleo combustível para navios (bunker) com baixo teor de enxofre, atendendo exigência da Organização Marítima Internacional, tratando-se, portanto, de um ativo lucrativo e importante para empresa nos dizeres da FUP (Cf. AEPET, 09/02/2021).

Outras refinarias já se encontram em estágio avançado de privatização, como é o caso da Refinaria Alberto Pasqualini (REFAP/RS), com negociação avançada com o grupo Ultra e da Refinaria Lubrificantes e Derivados do Nordeste (LUBNOR/CE) e da Unidade de Industrialização do Xisto (SIX/PR), que já receberam proposta de compradores de acordo com comunicados da Petrobras.

Esse é um movimento contrário ao de muitas outras petroleiras pelo mundo. A Petrobras, que se caracterizou por ser uma empresa integrada, indo do poço ao posto ou mesmo até o "poste", com seus investimentos em geração de energia elétrica -, agora vem se desintegrando. Colocando à venda ativos de todos os setores, inclusive ativos estratégicos como as refinarias. O setor de refino integrado à produção de

\footnotetext{
${ }^{21}$ Conforme nota da AEPET de 09/02/2021. Disponível em http://aepet.org.br/w3/index.php/conteudogeral/item/5828-rlam-esta-sendo-vendida-por-metade-do-preco-privatizacao-cria-monopolio-regional. Acesso em fev 2021.
} 
petróleo é extremamente estratégico para o controle de caixa operacional das petroleiras, pois tendencialmente o lucro das petroleiras provem em maior parte do refino em cenários onde se tem uma volatilidade do preço do petróleo (AEPET, 2019). Além desses aspectos haveria riscos de se consolidar um monopólio regional na produção e distribuição de combustível, condicionando o fornecimento dos mesmos a preços de monopólio regionais ou internacionais.

\subsubsection{A privatização da distribuição de combustíveis}

Além da venda de ativos do upstream e midstream, a gestão atual também faz liquidação do downstream. Nesse segmento a Petrobras já vendeu parte de sua participação nas subsidiárias BR Distribuidora, na Liquigás e Gaspetro conforme aponta o quadro 06.

Quadro 06: Ativos vendidos do segmento de distribuição da Petrobras entre 2015 e 2019

\begin{tabular}{|c|c|c|c|c|}
\hline \multicolumn{5}{|c|}{ Venda e Distribuição de Combustível (dowstream) } \\
\hline Transação & Localização & Ano & $\begin{array}{c}\text { Valor } \\
\text { (bilhões de } \\
\text { dólares) }\end{array}$ & Comprador \\
\hline $\begin{array}{c}\text { Venda de 49\% da } \\
\text { Gaspetro }\end{array}$ & Brasil & 2015 & 0,54 & Mitsui (Japão) \\
\hline $\begin{array}{c}\text { Venda de 28,75\% das } \\
\text { ações da BR distribuidora }\end{array}$ & Brasil & 2017 & ND & $\begin{array}{c}\text { Acionistas em Bolsa de } \\
\text { Valores }\end{array}$ \\
\hline $\begin{array}{c}\text { Venda de 33,75\% do } \\
\text { capital da BR Distribuidora } \\
\text { por meio de Oferta } \\
\text { Pública de Distribuição } \\
\text { Secundária de ações } \\
\text { (atualmente a Petrobras } \\
\text { detêm tão somente 37,5\% } \\
\text { da empresa). }\end{array}$ & Brasil & 2019 & 2,55 & $\begin{array}{c}\text { Acionistas em Bolsa de } \\
\text { Valores }\end{array}$ \\
\hline $\begin{array}{c}\text { Venda total da Liquigás } \\
\text { TOTAL }\end{array}$ & Brasil & 2019 & 3,7 & $\begin{array}{c}\text { Copagaz (Itausa) e a } \\
\text { Nacional Gás Butano }\end{array}$ \\
\hline
\end{tabular}

Fonte: Notícias nos sites dos jornais Valor, G1, Folha de São Paulo, Revista Exame, Fatos e Dados, Agencia Petrobras, Epbr e Relatórios anuais da Petrobras (2017 - 2019). 
Inicialmente, vale destacar o caso da BR distribuidora. Ela era a subsidiária mais lucrativa da estatal. Até $2017,100 \%$ de seu capital pertencia à Petrobras. No referido ano, a petroleira vendeu $28,75 \%$ de suas ações na bolsa de valores por aproximadamente 5 bilhões de reais. Em 2019 vendeu mais 33,75\% da subsidiária, também diretamente na Bolsa de valores. Assim, a composição acionária atual da BR Distribuidora é de $62,5 \%$ dos acionistas e $37,5 \%$ da Petrobras. No que se refere à Gaspetro, subsidiária da Petrobras que atua nas atividades de comercialização, importação, exportação, armazenamento e distribuições de gás natural, a atual gestão da Petrobras já sinalizou o desejo de vender seus $51 \%$ de participação restantes, pois já havia vendido $49 \%$ em 2015, para a japonesa Mitsui, e pretende encerrar suas participações na empresa. ${ }^{22}$ Finalmente, a Liquigás, que era uma subsidiária integral da Petrobras e atuava no engarrafamento, distribuição e comercialização de gás liquefeito de petróleo (GLP) no Brasil. A empresa tinha uma rede de aproximadamente 4,8 mil revendedores autorizados, tendo cerca de $21,4 \%$ de participação de mercado. Foi totalmente vendida para o consórcio formado por Copagaz (Itausa) e a Nacional Gás Butano. A Copagaz comercializa cerca de 620 mil toneladas de GLP por ano. É a quinta maior empresa de GLP do Brasil. A Nacional Gás Butano é a empresa de energia do Grupo Edson Queiroz que atua na distribuição de GLP em todo o Brasil. Já a Itausa é uma holding de investimentos ligadas ao banco Itaú.

Essas posições, em particular no mercado de gás, vão no sentido de uma resolução do Conselho Nacional de Política Energética (CNPE) de 24/06/2019 de "liberar o mercado de gás no país" (Veja, 24/06/2019). Ainda falta vender as Unidades de Tratamento de Gás, para quando?

\footnotetext{
${ }^{22}$ Ver mais em: https://www.seudinheiro.com/2019/petrobras/petrobras-conversa-com-mitsui-sobrevenda-de-participacao-na-gaspetro/. Acesso em fev. 2021.
} 


\section{O enquadramento pelas leis e sua interpretação pelos tribunais como forma de legitimação do Estado soberano à privatização}

Quando se verifica a construção empírica do enquadramento constitucional e do regramento infraconstitucional por meio de leis e de decretos, colocamo-nos no centro de um vasto debate de relações de poderes que revelam a direção geral que o governo, no seu sentido largo, tem dado ao setor de petróleo e, claro, à Petrobras. Isso se inscreve na multiplicação de ações jurídicas que decorrem dos conflitos de interesses diversos, como anunciamos no início, a partir de Foucault, a propósito do enquadramento da concorrência e da extirpação do Estado das atividades econômicas.

A lei do petróleo do governo Fernando Henrique Cardoso de 1997 (Lei n. 2.478), que acabou de fato com o monopólio da exploração e produção do petróleo pela Petrobras, não pôs fim, e não poderia fazê-lo sem uma mudança da Constituição, ao monopólio da União sobre esta fonte de energia, que é assegurado pelo Art. 177 da Constituição. Porém, com a Emenda Constitucional no 9 de 1995, a União teve a possibilidade, por meio da aprovação de uma lei, de contratar com empresas estatais ou privadas para a realização das atividades consideradas de monopólio natural.

Esse mesmo artigo 177 da Constituição também assegura, como monopólio da União, o refino, o transporte marítimo, a exportação e importação de petróleo e gás, bem como o transporte por meio de dutos, de petróleo bruto, seus derivados e o gás natural de qualquer origem, que, como a produção e exploração do petróleo, podem ser concedidos conforme a emenda número 9 da Constituição invocada. Depreende-se, assim, que tanto as refinarias como os gasodutos e as empresas de transporte do gás e do petróleo, que eram de propriedade da Petrobras e que é controlada pelo Estado, não poderiam ser privatizadas por se associarem ao monopólio invocado. Supondo-se que a Petrobras, por ser o representante do Estado na exploração do monopólio discricionário do Estado, não poderia, também, ser privatizada em função de sua associação intrínseca a esse monopólio desde sua fundação, salvo a Constituição é modificada. A própria lei de desestatização, Lei 99.491 de 1997, e aquelas que se seguiram, não incluíram a perda de controle acionário da Petrobras dentre seus objetivos. 
Conforme nos diz Paulo César Ribeiro LIMA (2020), se a Petrobras tem coligadas que fazem parte do grupo Petrobras e que controlam o setor de transporte (os gasodutos TAG e NTS) e/ou ativos que são diretamente ligados à empresa como as refinarias, estes setores e estas coligadas não podem ser vendidos. Deste modo, o CADE (Conselho Administrivo de Defesa do Consumidor), como foi feito recentemente, não tem competência para avalizar um termo de compromisso com a Petrobras para que ela venda suas refinarias por "possuir monopólio" no setor, monopólio que é assegurado pela Constituição, como vimos, bem como o STF não poderia ter autorizado a venda das refinarias.

O STF, por sua vez, autorizou, também a venda de controle acionário de coligadas da Petrobras, mas estas coligadas são ativos da empresa, portanto, segundo a Constituição, eles não poderiam ser vendidos ou se deveria ter uma lei específica para fazê-lo. A desestatização realizada por meio da criação de empresas de fachada coligadas ou subsidiárias, como também foi feito recentemente, para transferir, de maneira excusa, o patrimônio da Petrobras para elas e, seguida, ser vendido, também é obviamente ilegal. Por outro lado, estes mesmos ativos que foram vendidos, sem poderem, têm uma dupla ilegalidade, uma vez que foram alienados em sua maioria sem a devida licitação a que toda empresa pública ou mista deveria se submeter, e isso foi avalizado pelo TCU (Tribunal de Contas da União).

Assim, tanto o TCU, como o STF e o CADE (Conselho Administrivo de Defesa do Consumidor) validaram transações com os ativos da Petrobras que são inconstitucionais ou ilegais, pois deveriam prescindir de uma lei ou ter a Constituição alterada ou ainda a venda deveria ser feita com uma licitação. O que se nota é que o tribunal superior, o tribunal administrativo e o órgão de controle da concorrência têm suas sentenças totalmente fundadas no neoliberalismo, na jurisprudência construída como relação política. Assim, interpretam as leis com o horizonte neoliberal, mesmo que ele esteja em franca contradição com partes da lei maior, que, diga-se de passagem, é ela mesma eivada de artigos que muitas vezes são contraditórios entre si. Mas a validade de uma decisão, é, assim, decidida pelas relações de força no interior do Estado e legitimada pelos tribunais conforme a orientação geral do neoliberalismo dominante. Nesse 
sentido, o Estado soberano decide por meio de seus tribunais e governos que deve ser obedecido, invocando a soberania da lei e do próprio Estado que estaria acima de todos. Assim, depreende-se, como vimos anteriormente, que invocar a soberania do Estado para combater a mesma soberania invocada pelos órgãos do Estado acaba não surtindo efeito, uma vez que esse Estado está penetrado dos preceitos neoliberais que são invocados, também, como soberanos. O Estado invoca o obedecimento ao Estado para desconstruir a empresa-Estado.

\section{Considerações finais}

Quais os interesses efetivamente materiais nestas privatizações para o Estado brasileiro e para o conjunto dos interesses comuns de um certo "desenvolvimento"? Pensamos que nenhum, pois se transfere principalmente para empresas transnacionais e para grupos financeiros e de empresas brasileiras privadas, setores essenciais para a integração territorial e a circulação. Esses setores estão intimamente associados ao modo dominante de transporte hoje, o modal rodoviário e a circulação por navios e aviões: produção, tranformação, circulação e distribuição de combústiveis e de energia que se inserem num aspecto mas amplo internacional, primeiro Sul-americano e Latinoamericano, em seguida, global, com as relações complexas e sobrepostas das redes multinacionais e dos interesses geopolíticos.

Inúmeras estratégias buscam, por meio das práticas discursivas da direção da empresa e do governo brasileiro, desviar a atenção sobre os reais objetivos nesta desconstrução da Petrobras. Neles, como indicamos, se associam objetivos bem concretos de ganhos substanciais de agentes nacionais mediadores da desestruturação da empresa, que têm interesse no processo de privatização e desnacionalização. Para isto são invocadas uma série de suposições baseadas na internalização no Estado dos preceitos empresariais de mercado e em sua suposta maior eficacidade teórica da concorrência. O mercado vigiando o Estado do interior, por meio dos orgãos reguladores do próprio Estado, pelos tribunais e, finalmente, pelos responsáveis de diversos setores de governo. Retira-se, 
assim, a empresa do controle do Estado e a submetem ao controle de empresas transnacionais e do mercado financeiro, em particular dos fundos de investimentos.

Ora, quando se analisa tanto os movimentos de mercado instáveis do setor, quanto os resultados em termos de emprego, as decisões dos dirigentes da empresa apoiados em uma linha defendida pelo ministro da economia do Brasil a partir de 2019, obedecem a uma lógica e a uma "racionalidade" de ganhos, mas não aquela de um "livre mercado", mas a da um livre mercado a serviço de alguns, capturando a ideia de "liberdade" econômica.

Esta onda neoliberal brasileira, que se iscreve numa onda neoliberal sul-americana e que está associada a um neoimperialismo rampante, encontra suas razões no conjunto dos movimentos da economia-mundo e dos processos históricos constitutivos da sociedade brasileira, os quais serão analisados em outro momento de nossa pesquisa.

O espaço econômico é utilizado como sendo dotado de uma racionalidade de competição própria que pretende tornar o "mercado" uma solução e, portanto, justificando o "menos Estado", mas com o Estado elaborando e legitimando estas ações por meio das normas e de uma regulação amputada, onde entra em linha de conta os interesses representados pelas leis e suas legitimações produzidas por uma classe social sem "pactos", sem coalizões, mas tão somente contando com interesses de grupos empresarias e financeiros das classes dominantes brasileiras em acordo com as multinacionais.

A desestruturação da empresa-rede que atravessa e ocupa vastos territórios nacionais e cujo papel, para além da produção, transformação e distribuição de óleo e gás, é também social, leva em conta os preceitos neoliberais da empresa como modelo de vida, mas não a empresa estatal que é tratada de todos os males, mas a empresa de um grupo de individuos de preferência multinacionais e que constituem monopólios internacionais e nacionas, o que é passado sob silêncio, pois o único monopólio que de fato incomoda é o do Estado, desconsiderando-se, assim, todo o acúmulo coletivo na construção do grupo Petrobras ao longo de quase 70 anos e privilegiando-se os ganhos individuais obtidos graças à intermediação do Estado. 
Parece que esta ideia de uma empresa nacional que componha uma série de conjunções de interesses de classe e que tenha um "serviço social" está alijada do campo de possibilidades de ação atualmente, por isso a desestruturação da empresa, mesmo que se faça em momentos do capitalismo de guerra, aproveitando de incertezas, de crises politico-econômicas e sanitária atuais. Isso encontra, apesar da resistência dos sindicatos e dos setores de trabalhadores mais aguerridos, uma ressonância no espaço social onde a reprodução do slogan neoliberal e da privatização a qualquer custo indicam um recuo do papel social e econômico do Estado e uma acentuação de sua legitimidade soberana para impor o obedecimento às suas decisões, mesmo que contrárias aos interesses coletivos. Recuo paradoxal e fundado sobre uma "governamentalidade" empirica e experimental que corroi aos poucos as bases sociais da empresa (redução de número de trabalhadores, de salários, de presença nos territórios, de intervenção na arena pública, de apoio aos projetos de desenvolvimento, de inovação etc.).

Como explicar este momento de "individuação" e de "subjetivação", no sentido foucatiano de construção de subjetividades pelas ações e retroações do meio e na produção de uma individuação, que reage ao meio sob a forma de sucessivas adaptações/conversões às práticas discursivas dominantes que penetram em todas as esferas sociais dos individuos?

Pensamos que, por mais que se invoque a propósito da privatização e, em consequência, de uma relativa desnacionalização da Petrobras, o "crime de lesa pátria" e a perda de "soberania", este grito do coração dos militantes e trabalhadores da empresa não tem mais a repercussão social que tinha antes. As "veridições" neoliberais (FOUCAULT, 2004) produzidas pela empresa e pelas práticas dentro das empresas e do próprio governo levam a conquistar uma espécie de hegemonia provisória, que não vai sem contradição, sobre parte dos individuos trabalhadores da empresa, bem como de outros setores sociais. Como sair deste impasse? Por uma tomada radical de posição pela retomada da empresa nos quadros de uma economia neoliberal sem que se mude o conjunto das práticas sociais? 
Nos parece que os trabalhadores do grupo Petrobras estão cindidos entre seu interesse próprio e o interesse da empresa e de sua direção e do governo que ainda a controla, cindidos contra eles mesmos, de um lado vivendo no sentido da urgência da cooperação e do coletivo para enfrentar a direção da empresa, de outro submetido aos discursos e práticas sociais do neoliberalismo que justificam os processos dentro de própria empresa (conforme o apoio muitas vezes paradoxais de parte de trabalhadores, segundo entrevistas que realizamos em 2018 e 2019, à direção da empresa no processo de privatização). Parece não se tratar de "consciência", mas de ser pego nas tramas das relações de poder dentro da empresa que externalizam e internalizam os "valores" neoliberais, a "liberdade" de mercado associada à "liberdade" de ação (FOUCAULT, 2004).

O trabalho produtivo, no sentido dado por Marx, que deu mais-valor à produção da Petrobras como empresa, que tem uma divisão do trabalho complexa e extensa juntamente com a sua inserção espacial e territorial ajudaram a definir a empresa no passado como modelo de Estado e de construção do Estado Nacional. Assim, ela se desenvolveu em concomitância com "formação contemporânea do Estado nacional", e, desse modo, se consolidou com uma grande empresa de exploração, produção e transformação de óleo e gás. Paradoxalmente, isso se encontra no coração do capitalismo como combustível e azeitamento da máquina de produção, revelando seu papel socioeconômico também cindido: de um lado a formação nacional, de outro a plena participação no capitalismo, o que certamente favorecera sua inserção nos mercados de capitais nos anos 1990, seu destino dependendo de coalizões de poder.

Ora, esta empresa-Estado se transforma e seu espelhamento do Estado tem como retorno hoje a imagem do neoliberalismo. Assim, o modelo de empresa social e territorial, exemplo de lutas históricas face ao imperialismo e aos interesses privatistas das classe dominantes nacionais, aliadas privilegiadas dos grandes capitais internacionais, não se inscreveria mais sobre um solo de realidade nacionaldesenvolvimentista, com a continuidade da produção de verdadas que lhe permitissem ser a coextensão empresa-Estado na ideia de um Estado nacional soberano do tipo 
intervencionista. Essa realidade foi substituída pela governamentalidade neoliberal, quer dizer, por processos que agem no interior do governo empresarial e do governo politico do Estado que se acentuam e se apoiam em rede, reciprocamente, por meio de práticas de concorrência, de disputas e das "liberdades" que se jogam e têm como modelo o mercado. O mercado será o momento da veridição, da justificação de si e dos outros, da constituição da subjetividades, replicado que é na "alma" dos governantes e dos governados.

A soberania, como dissemos, parece estar cindida: de um lado ela é invocada pelos que defendem a empresa sob o controle do Estado e voltada para os interesses coletivos, de outro lado, os que invocam a soberania como forma de controle sobre as fronteiras nacionais e utilizando os signos nacionais e a ideia do "inimigo interno" identificados como os que são contra a privatização da empresa e do próprio Estado. Os soberanistas que usam as práticas da guerra social estão profundamente identificados ao neoliberalismo, procurando implementá-lo mesmo que seja à força e utilizando a noção de "lei e ordem" dos neoliberais no sentido amplo de impor ordem a toda a sociedade. Mas os soberanistas "progressistas" e de esquerda do "nacional-desenvolvimentismo" não estariam, quando invocam a soberania sem nenhuma análise mais crítica desse conceito, subscrevendo, mesmo que involuntariamente, aos preceitos da submissão a um Estado soberano que se legitima invocando a soberania popular confundida com a soberania estatal, que, como vimos, não é mesma coisa? Isso pode contribuir para a confusão e para a desmobilização crítica contra o Estado soberano que contra-ataca a soberania popular, submetendo-a e fazendo dela, por meio de uma espécie de prestidigitação, sua justificativa última, quando de fato se legitima o poder daqueles que controlam o Estado por meio de uma lei à geometria variável e uma partidarização do direito que tem consequências autoritárias indubitáveis.

\section{Referências bibliográficas}

AGÊNCIA BRASIL. 15/12/2020 disponível em https://agenciabrasil.ebc.com.br/economia/noticia/2020-12/excedente-de-oleo-dopre-sal-chega-74-na-producao-de-outubro e consultado em 05/02/2021. 
ANP - AGÊNCIA NACIONAL DO PETRÓLEO, GÁS NATURAL E BIOCOMBUSTÍVEIS. disponível em http://www.anp.gov.br/noticias/5231-anp-publica-pre-edital-darodada-do-excedente-da-cessao-onerosa. Acesso em 13 de junho de 2019.

ANP - AGÊNCIA NACIONAL DO PETRÓLEO, GÁS NATURAL E BIOCOMBUSTÍVEIS Disponível em http://www.anp.gov.br/agenda-de-eventos/sessao-publica-deofertas-da-rodada-de-licitacoes-do-excedente-da-cessao-onerosa. Acesso em $23 / 11 / 2020$.

ASSOCIAÇÃO DOS ENGENHEIROS DA PETROBRAS (AEPET). Cláudio da Costa Oliveira. EBITDA: Indicador adotado pela Petrobrás é inadequado e métrica é ainda pior, em 05 Fevereiro de 2020. Disponível em http://www.aepet.org.br ASSOCIAÇÃO DOS ENGENHEIROS DA PETROBRAS (AEPET). 15 de abril de 2019. Disponível em http://www.aepet.org.br/w3/index.php/conteudo-geral/item/3034-presidente-daaepet-comenta-decisao-de-bolsonaro-sobre-o-diesel. Acesso em 19/04/2019.

ASSOCIAÇÃO DOS ENGENHEIROS DA PETROBRAS (AEPET). Cláudio da Costa Oliveira: Venda de ativos da Petrobrás gera bônus para seus diretores, 02 de Abril 2020 AEPET. Disponível em http://www.aepet.org.br.

ASSOCIAÇÃO DOS ENGENHEIROS DA PETROBRAS (AEPET). Cláudio da Costa Oliveira. $O$ roteiro para o fim da Petrobrás já está pronto e em andamento, 04 Março de 2020. Disponível no site da AEPET. Disponível em http://www.aepet.org.br.

ASSOCIAÇÃO DOS ENGENHEIROS DA PETROBRAS (AEPET). Décio Oddone (ANP) usa falácias para defender privatizações na Petrobrás. Felipe Coutinho, 29/04/2019. Disponível em http://aepet.org.br/w3/index.php/conteudo-geral/item/3068-deciooddone-anp-usa-falacias-para-defender-privatizacoes-na-petrobras.

ASSOCIAÇÃO DOS ENGENHEIROS DA PETROBRAS (AEPET). Entrevista Felipe Coutinho, presidente da AEPET, 2020.

ASSOCIAÇÃO DOS ENGENHEIROS DA PETROBRAS (AEPET). Março 2019. Disponível em http://www.aepet.org.br/w3/, acesso em 26/03/2019.

AEPET nota de 09/02/2021. Disponível em http://aepet.org.br/w3/index.php/conteudo-geral/item/5828-rlam-esta-sendovendida-por-metade-do-preco-privatizacao-cria-monopolio-regional.Consultado em $10 / 02 / 2021$.

ATAS do Conselho de Administração da Pré-sal Petróleo, disponíveis em http://presalpetroleo.gov.br/ppsa/governanca-corporativa/conselho-deadministracao, acessado em 05/02/2021). 
BRASIL 247. Disponível em: < www.brasil247.com>. Acesso em: 18 abr. 2018.

BRASIL Ministério das Minas e Energia. Portarias № 213 de 23/04/2019.

BRASIL. Leilão da cessão onerosa garante arrecadação de R\$ 70 bilhões.

BRASIL. Ministério das Minas e Energia. Portaria №251 de 13/06/2019.

BRASIL.https://www.gov.br/pt-br/noticias/energia-minerais-ecombustiveis/2019/11/leilao-da-cessao-onerosa-garante-arrecadacao-de-r-70bilhoes . Acesso em 23/11/2020.

BRENNER, N; PECK, J. ; THEODORE, Nik. Após a neoliberalização? Cad. Metrop. São Paulo, v.14, n.27, pp.15-33, 2012.

CARTA CAPITAL. As suspeitas de "negócios ocultos" do ministro Paulo Guedes. Disponível em https://www.cartacapital.com.br/economia/as-suspeitas-de-negocios-ocultosdo-ministro-paulo-guedes/.Consultado em 09/02/2021.

CLICK PETRÓLEO. Disponível em https://clickpetroleoegas.com.br/petrobras-informa8816-bilhoes-de-barris-de-petroleo-com-reservas-provadas-em-2020/ Consultado e 08/02/2021.

DARDOT, Pierre ; GUÉGUEN, Haud ; LAVAL, Christian; SAUVÊTRE, Pierre. Le choix de la guerre civile. Une autre histoire du néolibéralisme. Québec : Lux Éditeur, 2021.

DARDOT, Pierre ; LAVAL, Christian. Dominer. Enquête sur la souvéraineté de l'État en occident. Paris: La découverte, 2020.

DARDOT, Pierre; LAVAL, Christian. Comum. Ensaio sobre a revolução no século XXI. São Paulo: Boitempo, 2017.

DEMONSTRAÇÕES financeiras da Petrobras de 2017 e 2018. http://www.investidorpetrobras.com.br/pt/governanca-corporativa/capital-social. Acesso em 24/10/2018 e 19/05/2019.

DOWBOR, Ladislau. A era do capital improdutivo. São Paulo: Outras Palavras \& Autonomia Literária, 2017.

EPBR. https://epbr.com.br/marcio-felix-e-o-novo-vice-presidente-executivo-da-onip/, acessado em 30/11/2020.

ES GÁS. https://esgas.com.br/governanca-corporativa/ , consultado em 30/11/2020. 
ESPÍRITO SANTO (Estado). Secretaria de Desenvolvimento. Petróleo e gás natural. Disponível em: http://antigo.es.gov.br/EspiritoSanto/paginas/petroleo gas.aspx. Acesso em: 9 maio 2017.

FEDERAÇÃO ÚNICA DOS PETROLEIROS https://www.fup.org.br/component/k2/item/23905-venda-da-tag-e-ilegal-e-seracontestada-pela-fup.

FOUCAULT, Michel. A verdade e as formas jurídicas. Rio de Janeiro: NAU Editora, 2011 [1973].

FOUCAULT, Michel. Segurança, território e população. São Paulo: Martins Fontes, 2008a.

FOUCAULT, Michel. O nascimento da biopolítica. São Paulo: Martins Fontes, 2008b.

Jornal GGN de 28/02/2019, 7/3/2019 e 10/03/2019. Disponível em https://jornalggn.com.br/ . Acesso em maio 2019.

LAIER, Patricia. Patrícia Laier explica a Cessão Onerosa. AEPETV, 31/01/2019. Disponível em http://www.aepet.org.br/w3/index.php/conteudo-geral/item/2713-aepetvpatricia-laier-explica-a-cessao-onerosa.

LAVAL, C., PALTRINIERI, L., TAYLAN, F. Marx \& Foucault. Lectures, usages, confrontations. Paris: La Découverte, 2015.

LAVAL, Christian. Foucault, Bourdieu e a questão neoliberal. São Paulo: Editora Elefante, 2020.

LEÃO e NOZAKi (Org.). Energia e petrolíferas globais: transformações e crises. Rio de Janeiro: INEEP/Flacso, 2018.

LIMA, Paulo César Ribeiro. Análise da constitucionalidade e da legalidade das privatizações na Petrobras. Curitiba: Appris, 2020.

MACHADO, Marco Antônio Pinheiro. Pré-sal: a saga. A história de uma das maiores descobertas mundiais do petróleo. Porto Alegre: LP, 2018.

NASSIF, Luis. Jornal GGN, 29/03/2019. Disponível em https://jornalggn.com.br/ . Acesso em 29/03/2019.

ONIP. Disponivel em: https://www.onip.org.br/institucional/nosso-proposito, consultado em 30/11/2020.

PETROBRAS. Balanços da Petrobras, 2016,2017,2018 e 2019. 
Petronotícias. Disponível em https://petronoticias.com.br/confirmado-o-nome-demarcio-felix-para-secretaria-de-petroleo-e-gas-do-mme/, consultado em 05/02/2021.

PEREIRA JUNIOR, Edilson. Impactos da acumulação om predominância financeira sobre a nova Geografia industrial - processos produtivos, competitividade e diferenciação espacial. Revista Ateliê, 2018. Disponível em https://www.revistas.ufg.br/atelie/article/view/59279/34203.

PRÉ-SAL PETRÓLEO S/A. https://www.presalpetroleo.gov.br/ppsa/portal/default.php , consultado em 30/11/2020.

PESSANHA, Roberto. A "indústria" dos fundos financeiros. Potência, estratégias e mobilidade no capitalismo contemporâneo. Rio de Janeiro: Consequência, 2019.

RELATÓRIOS FINANCEIROS DA PETROBRAS. 2011 e 2017.

PORTAL G1. Resultado do megaleilão da cessão onerosa deixou a desejar, dizem especialistas. Disponível em https://g1.globo.com/economia/noticia/2019/11/06/resultado-do-megaleilao-dacessao-onerosa-deixou-a-desejar-dizem-especialistas.ghtml . Acesso em $\underline{23 / 11 / 2020}$.

REVISTA EXAME. Datadas de 15/03/2019, 8/04/2019, 9/04/2019. Disponível em https://exame.abril.com.br/revista-exame/.

ROBERTO CASTELLO BRANCO. Disponível em http://www.aepet.org.br/w3/, acesso em 26/03/2019.

ROSA, Gustavo. Combate à corrupção na Petrobras: quando interesses geopolíticos, econômicos e de política doméstica se entrelaçam. Disponível em: < https://jornalggn.com.br/>. Acesso em: 20 jan. 2018.

SAUER e RODRIGUES. Pré-sal e Petrobras. Além dos discursos e mitos: disputas; riscos e desafios. Estudos avançados, 30(88), 2016, p.185-229.

SAUER, Ildo Luís; ESTRELLA, Guilherme de Oliveira. Nota técnica. Avaliação do leilão do óleo excedente dos campos da Cessão Onerosa. Instituto de Energia e Ambiente, Universidade de São Paulo, 2019.

SAUER, Ildo Luís; ESTRELLA, Guilherme de Oliveira. Nota técnica. Avaliação do leilão do óleo excedente dos campos da Cessão Onerosa. Instituto de Energia e Ambiente, Universidade de São Paulo, 2019.

SOUZA, Jessé. A elite do atraso. Da escravidão à Lava Jato. Rio de Janeiro: Leya, 2019. 
SUPREMO TRIBUNAL FEDERAL (STF). Liminar do Ministro Ricardo Lewandowsky deferindo a Ação Direta de Inconstitucionalidade questionando a lei das estatais $\mathrm{N}^{\circ} 13.303 / 2016$.

Disponível

em http://portal.stf.jus.br/processos/detalhe.asp?incidente=5093069. Acesso em 16/04/2019.

SUPREMO TRIBUNAL FEDERAL (STF). Medida Cautelar do Ministro Edson Fachin do de 11/04/2019, p.264, citando o parecer do presidente do STJ. Disponível em https://www.jusbrasil.com.br/diarios/236782029/stf-11-04-2019-pg164?ref=previous button. Acesso em 16/04/2019.

TELEGRAMA DA EMBAIXADA dos Estados Unidos, Brasília, datado de 30/10/2009 e divulgado pelo Wikileaks. Disponível em https://wikileaks.org/. Acesso em março de 2019.

THE INTERCEPT. As mensagens secretas da Lava Jato. Disponível em https://theintercept.com/brasil/. Consultado em 18/06/2019.

WERNER, Deborah. Rodadas de neoliberalização, provisão de infraestrutura e "efeito China" no Brasil pós-1990. Eure, vol. 46, no 139, setembro de 2020, p.143-162.

ZANOTELLI, C. L. DOTA, E.M; FERREIRA, F. C. Esboço de uma bacia urbano-regional do petróleo entre a zona costeira do Espírito Santo e do Rio de Janeiro in: XV simpurb, 2017, Salvador. Anais do XV Simpurb. Salvador: UFBA, 2017. p.1-25.

ZANOTELLI, C; Medina, J.L.; FERREIRA, F.C.; ADÃO, M.O.F. A notícia como máquina de guerra. Análise dos discursos sobre a Petrobras e a produção de petróleo e gás nos jornais: um enfoque no Espírito Santo. Vitória: Edufes, 2020.

ZANOTELLI, Cláudio. O polo de Tubarão e a expansão periférica da aglomeração de Vitória. Tese de doutorado, Universidade de Nanterre, 1998.

ZANOTELLI, C. Elementos preliminares sobre a financeirização e a geografia política da crise no Brasil In OLIVEIRA, F.G.; OLIVEIRA, L.D.; TUNES, R.H.; PESSANHA, R.M. Espaço e economia. Geografia econômica e a economia política. Rio de Janeiro: Consequência, 2019, p. 511-552. 